\title{
The production of contested landscapes: Enclosing the pastoral commons in Niger
}

\author{
Julie Snorek ${ }^{\text {a, }}{ }^{*}$, Linda Moser ${ }^{b}$, Fabrice G. Renaud ${ }^{c}$ \\ a United Nations University, Institute for Environment and Human Security (UNU-EHS) Germany, Institute for Environmental Science and Technology \\ (ICTA), Autonomous University of Barcelona (UAB), Spain \\ ${ }^{b}$ German Aerospace Center (DLR), German Remote Sensing Data Center (DFD), Germany \\ ${ }^{c}$ UNU-EHS, Germany
}

\section{A R T I C L E I N F O}

\section{Article history:}

Received 10 August 2016

Received in revised form 20 January 2017

Accepted 26 January 2017

Available online 24 February 2017

\section{Keywords:}

Divergent adaptation

Remote sensing

Common pool regimes

Land use/land cover change

Agro-pastoralism

Niger

\begin{abstract}
A B S T R A C T
Divergent adaptation to climate variability produces unequal adaptive capacities between user groups and contributes to a contested landscape. This article examines divergent adaptations in the context of land tenure shifts in the pastoral zone of Niger. The management of the pastoral commons is shifting from a commonly-shared to private regime as former pastoralists take up new livelihoods, such as irrigated gardening. A method combining political ecology and remote sensing is used to study social ecological system (SES) dynamics in order to demonstrate the relationship between divergent adaptation, water-based conflict, land tenure shifts and land use/land cover change. Examining pastoral and agro-pastoral users' historical perceptions of land use and tenure change, results indicate that disputes over the access to and use of commonly shared natural resources are linked to increasing enclosures of ephemeral and permanent lakes in the pastoral zone of Niger. Remote sensing-derived information is used to identify and quantify the area and volume of enclosures around commonly shared water sources in the northern pastoral zone of Niger from 2003 to 2013. The study identifies the government-supported development of irrigated gardens in the pastoral zone as a divergent adaptation with its related conflict dynamics between user groups and highlights the land tenure shifts from a commonly to a privately managed regime. The findings have broader implications for the wider Sahel and provide recommendations as to how adaptation programs could be better designed and implemented in the pastoral system.
\end{abstract}

(C) 2017 Elsevier Ltd. All rights reserved.

\section{Introduction}

\subsection{Defining the contested landscape}

Divergent adaptation (Snorek et al., 2014) describes how adaptation to climate change within a social-ecological system (SES) produces the potential for greater inequities, conflicts, and/or cooperation resulting from adaptation decisions. The term divergent adaptation is defined as 'those adaptations that promote the adaptive capacity of one individual/community in a shared ecosystem which leads to a reduced adaptive capacity of an alternative individual/community in the same ecosystem,' and through this process, one can identify which users win or lose in adaptation,

\footnotetext{
* Corresponding author.

E-mail address: juliesnorek@gmail.com (J. Snorek).
}

enhance adaptive capacity for marginalized groups, and promote equal adaptive capacity in the adaptation process (Snorek et al., 2014: 372). Divergent adaptation is related to unsustainable and unequal forms of development and adaptation (Smith, 1990; Eriksen et al., 2011) and policies that have promoted land use conversion and/or sales that, in turn, dispossess small holders, reducing their adaptive capacity (Mardsen, 1995; Adger et al., 2006; Peluso and Lund, 2011; Cotula, 2012). The Inter-Governmental Panel on Climate Change (IPCC)'s AR5 chapter on human security (Adger et al., 2014), as well as other literature highlights how adaptations can enhance inequalities, impact resilience and disrupt overall human security of an SES (Raleigh, 2010; Eriksen et al., 2011; Kloos et al., 2013; Snorek et al., 2014).

Contested landscapes and how and why they are contested has been illustrated in previous research (Bender, 1998; Robinson et al., 2009; Duinveld and Van Assche, 2011). Socio-geographical spellings of landscape point to the impact of humans in altering the 
physical landscape (Birks et al., 1988) and in the redefinition of rural spaces (Mardsen, 1995; Reyes-García et al., 2014). Historically, landscape is in effect a progressive debate amongst societies and cultures (Cosgrove, 1984), which is expressed through man's adaptation of nature in the effort to satisfy his needs (Bryan, 1931). Contested landscapes are shaped by multiple and contradictory discourses (Pollini, 2010) as well as large-scale land use changes (Lukas, 2014). To contribute to this discussion, we define 'landscape' as the physical and psychological manifestations of space, represented by social and ecological phenomena that can be described by observation. The significance of divergent adaptations on the landscape emerges in the manifestations of peoples' diverse relationships with landscape, and how social, political, and economic factors influence this relationship and conflict dynamics (Cosgrove, 1984; Robbins, 2012).

As common pool resources become mapped into divisible, saleable space (Bender, 1998), laws establishing property rights and the commoditization of parcels of the social ecological landscape promotes fractured and divided systems, bought and sold for their relative benefits (Illich, 1983). The transformation of commons through enclosure essentially dispossesses small holders of their rights to the landscape, such as the division of the English landscapes and enclosure of common fields dispossessing English commoners (Barrell, 1983; Bermingham, 1986). Recent studies in Ethiopia (Schmidt and Pearson, 2016) and Bolivia (Reyes-García et al., 2014) relate government policies and economic development programs to changing land rights and land tenure regimes, resulting in a scramble for land claims in a former commonly governed territory. Those who have lost their livelihoods through this process of enclosure increasingly fall into abject poverty and dependency on those who have taken it away (Goldsmith et al., 1992).

The process of moving from a common pool to private property regime produces a contested and disputed landscape (Mardsen, 1995; Cheria and Edwin, 2011). These processes of uneven development have been exemplified also in adaptation processes (Eriksen et al., 2011) and divergent adaptation (Snorek et al., 2014). Like the poverty reducing sedentarization schemes in Ethiopia (Schmidt and Pearson, 2016) and the fragmenting of indigenous peoples' territories for the purpose of land reconfiguration (ReyesGarcía et al., 2014), divergent adaptations to climate events in Niger (Snorek et al., 2014) tend to exclude certain users, creating the potential for further marginalization and conflict. The dynamics of divergent adaptation can be visualized as 'inscriptions' on the landscape through remote sensing (Lukas, 2014) if they are sufficiently described through a solid analysis of historical environmental and social dynamics that identify the space as a contested landscape (Robbins, 2012).

\subsection{Using geospatial analysis in a contested landscape}

Deriving a correlation between geo-observed land use changes and conflicts at the landscape scale requires views from above and strong contextual understanding from below (Turner, 2003). Medium to low spatial resolution remote sensing data $(250 \mathrm{~m}-4 \mathrm{~km}$ pixel size) enable the detection of trends and anomalies of remotesensing derived indices or biophysical variables over large areas. Applications in the Sahel include studies on the dynamics of vegetation, land use, and land degradation (Dardel et al., 2014; Brandt et al., 2014a; Horion et al., 2014; Mbow et al., 2015), water bodies and wetlands (Moser et al., 2014) and precipitation (Nicholson, 2005). Yet, such data is insufficient to elucidate more specific social-land use practices (Turner, 2003), for which the use of high to very high spatial resolution data is required (Elmqvist and Khatir, 2007; Brandt et al., 2014b).
Analysis of linkages between social conflict and environmental change demands strong analysis of the social ecological landscape (Lukas, 2014; Witmer, 2015). Only a few recent remote sensing studies in Africa (Turner, 2003; Akiwumi and Butler, 2008) shed light on the discrepancies between human interactions and shifts in land use. Integrating remote sensing analysis and political ecology principles as an approach has permitted the examination of social and ecological changes across a landscape (Nyerges and Green, 2000; Turner, 2003; Lukas, 2014). Lukas (2014) uses this approach to examine land grabs by political elites and its relationship to soil erosion on hillsides, which in turn demonstrates how a contested landscape is 'inscribed' with human and environmental features that link back to historical conflicts. This approach provides multiple perspectives of land use and land cover change and permits a teleologically strong examination of the complexity of social struggles in rural systems (Turner, 2003).

Stemming from the theoretical underpinnings of divergent adaptation and its consequential cooperation and conflict dynamics, this paper presents a case study of a contested social ecological landscape in the pastoral zone of northern Niger. Inscriptions are manifested as enclosure of common pool water resources through irrigated agricultural development, prompted by productivist discourses related to climate change adaptation. These inscriptions can be analyzed through geospatial information and are also related to long-standing natural resource access conflicts. Such conflicts are, in turn, heavily influenced by the modes of adaptation that produce winners and losers, especially in the context of drought or other extreme climate events. Examined from the scope of these inscriptions, a combined political ecology and remote sensing approach explains and quantifies divergent adaptations (Snorek et al., 2014) in this contested space.

The paper is organized as follows: The following section 2 illustrates the pre-colonial and colonial context that has framed the contemporary contested landscape. Section 3 describes the mixed methodology for the case study. The results in section 4 demonstrate profiles of multiple users, land use and land cover change temporality, the conundrums of shifting land and water access regimes, economic impacts on livelihoods, and the role of institutions. The discussion in section 5 highlights contradictions in the development of Niger's pastoral system in the context of climate change and the conclusion provides a summary of the research methods, findings, and recommendations for future research.

\section{Context of Niger's pastoral system}

Human security in the Sahel has been precarious in the past two decades due to geo-political, social-ecological, and climatic forces. Over the course of the past fifty years, Niger has seen six major rainfall deficit events during 1973-1974, 1984, 1989, 2005, 2010, 2012 (FEWSNET, 2011), and rainfall variability is perceived to be increasing in frequency (Desanker and Magadza, 2001; Hengsdijk and van Kuelen, 2002). Niger has one of the highest rates of population growth in the world, ranging upwards to $4 \%$ per annum (World Bank Data, 2015). While the amount of farmland expanded at higher rates than the population in two decades prior to the turn of the Century, currently the lack of farmland and decreasing soil fertility of existing farmland is resulting in an overall decrease in cereal production (USGS, 2012). Reforestation or re-greening have improved soil health in some cases (Dardel et al., 2014), yet the pace of population growth has surpassed the ecological capacities within the region, deepening the poverty and vulnerability of some communities (Tschakert, 2007). Furthermore, the fall of the Libyan regime in 2011 has been accompanied by multiple shocks to human security - an influx of arms prompting rebellion movements, more 
dangerous migrant routes, shifts in remittances due to repatriated migrants, and an influx of security-based aid to northern Niger (Snorek, 2016). These threats to human security may have deleterious effects on natural resource management challenges in the Sahel, which is based upon broad and diverse strategies of control and appropriation (Mohamadou, 2010), dependent upon rivalries and alliances that unite or divide the many competitors and partners in the social ecological system (SES).

\subsection{Niger's first enclosures}

To prevent the extension of agriculture into the pastoral regions of Niger, the colonial government traced a 'northern limit of cultivation' in 1953 (Mohamadou, 2010). In one of his first acts as president in 1961, Hamani Diori visited the pastoral zone in Northern Niger. Following this visit, a governmental decree, which later was made Law 61-005 (27 May 1961, Fig. 1) authorized a separation of north from south, establishing an official limit to cultivation and pastoral zone (south of what was then the $350-\mathrm{mm}$ rainfall isohyets). Law 61-005 was a novel way to protect pastoral space and serves as the first post-colonial state enclosure. New rain-fed cultivation is forbidden in the pastoral zone (Article 1 Law 61-005), but oasis or irrigated cultivation (Article 4) is permitted. On the contrary, the appropriation of land is not allowed (Article 5). The new border to the pastoral activities did not stop the northward migration of farmers seeking land, especially with the abolition of slavery, and this line of cultivation continues to march northward every season.

\subsection{Divergent adaptation triggered by the two great droughts}

The two extreme droughts in 1973-74 and 1984-85 (Fig. 1) fundamentally reshaped the landscape of the pastoral zone, including species diversity and abundance. President and General Seyni Kountché came to power through a coup d'état in 1974, promising to prevent the famine that was endured during the drought (Fig. 1). The president attributed much of the famine to the small holders' lack of control over land, which they worked in order to pay patronage to local chieftains. In a broad-sweeping change in the patron-tenure status of land, the president gave a radio address that has since become known as the 'land to the tiller' speech (December 18, 1974) (Ngaido, 2000). While not backed by any legislation (Ngaido, 1995), his statements established new land tenure norms that undermined the tenant farmer regimes, which gradually promoted the clearing of vast areas of land that had previously not been cultivated. Participants stated the period of 1984 's famine as a 'turning point' that steadily brought on more and more degradation including a loss of open (pastoral) space and highly concentrated cultivated (privatized) space.

During his tenure as governor of Tahoua (1981-1988), Mahamadou Tandja encouraged pastoralists who had lost their livestock in 1984 to plant fields or gardens in the valleys. The government gave them land and tools to start gardening, which brought about the first garden plots in the valleys around the pastoral zone. While some pastoralists managed to reconstitute their herds and returned to pastoral livelihoods, the sedentarization had already attracted landless migrants (primarily Hausa) from the South, who also settled in villages in the valleys.

\subsection{Pastoral livelihoods, vulnerabilities and adaptations}

The common Tamashaq phrase (Tuareg) "amman imman, akh issudagh," or "water is life and milk is food" typifies life in the SES. The pastoral zone receives an average of $100-250 \mathrm{~mm}$ of rainfall per annum during a 3- to 4-month rainy season (July to September).
Rainfall determines the amount and abundance of grassland biomass, which is es3timated at an average of $2.5 \mathrm{~kg} / \mathrm{ha}$ for $1 \mathrm{~mm}$ of rain (Hammel, 2005), and the quantity of water in ephemeral and permanent lakes. The activity of actors in the SES is influenced by rainfall, the quality and type of soil, water access, types of vegetation, and local institutions.

Multiple actors are present in the pastoral zone: 1) local pastoralists or those nomadic and semi-nomadic groups who dwell year-round in the pastoral zone, 2) transhumant herders who typically shepherd their and others' livestock to the northern pasture only during the rainy season, and 3) those former pastoralists and landless agriculturalists cultivating rain-fed and irrigated plots of land. When rains begin in June, transhumant herders leave the southern agricultural and agro-pastoral zones, some crossing multiple national boundaries to arrive in Niger's pastoral zone. These northern migrations, coupled with the large size of herds are perceived as factors that overwhelm the fragile grassland ecosystems (Touré, 2015; Snorek et al., 2014). The expansion of croplands further degrades the fragile ecosystem, reducing overall biodiversity and biomass (Dube and Pickup, 2001) as well as water infiltration.

Wetlands and lakes have strategic importance in the pastoral zone as an open access resource for multiple actors (Brouwer, 2009). Denudation of the land throughout Niger has promoted lakes to increase in size and the water table to rise as a result of higher runoff flows (Favreau et al., 2012). As waters recede, pastoralists dig wells in seasonal lakes, providing a temporary and free water source for several months after the rains have subsided. Those who are entitled to water access possess not only greater control over the surrounding natural resources (trees, pasture, soil), but also authority and influence. At certain periods of the dry season, the more sparsely distributed deep wells and pumping stations (boreholes) are the only available water source. Such water points are often poorly managed or in ill repair and typically require payment for use. During the annual soudure or period when resources are mostly depleted (April/May-June/July) pastoralists herd their livestock between water points and pasture areas, sometimes at extreme distances and at high morbidity levels of livestock. Drought adaptation includes the transport of hay and water to weak herds, at high monetary costs. More impoverished pastoralists have stated that these high costs have made their livelihoods untenable in light of climate variability, causing many to settle into towns despite strongly expressed desires to continue a pastoral (nomadic) livelihood (Snorek, 2016). This dichotomous transition within Niger's pastoral system is one representative example for a wider challenge facing societies across the globe that are adapting to climate change events and the related land vulnerabilities.

\section{Mixed remote sensing and qualitative methodologies}

\subsection{Overview of research design}

The research methodology consisted of ethnological and phenomenological approaches in qualitative research, highlighted and complemented by remote sensing-based data collection and analysis. Data collected during a first phase served to specify potential types of inscriptions and case study areas for the remote sensing study. The first phase of qualitative data collection was carried out from April to December 2011 in northern Tahoua, including the region of Tillia (Fig. 2). After a brief analysis of initial results, remote sensing data was acquired for Tillia and Droum during September 2012 and February 2014. Results of remote sensing analysis were then compared with a second phase of qualitative data collection in Tillia and Droum 


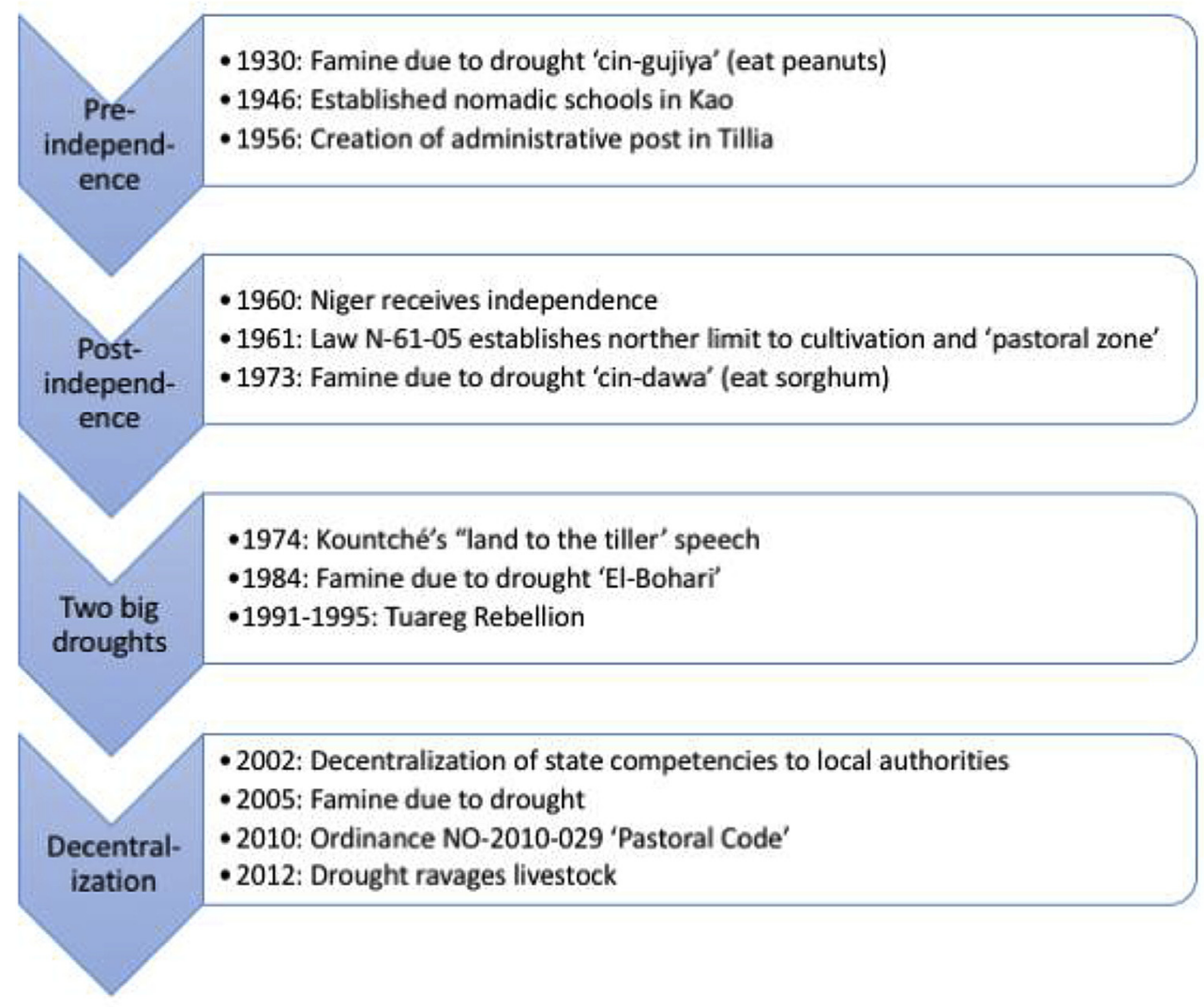

Fig. 1. Timeline of significant events impacting Northern Tahoua 1900 to present (own figure).

(November-December 2015). Droum was added in the second phase for comparison purposes. Data collection in Tillia and Droum was highly precarious due to security restrictions and thus was carried out by local field team members; conversations were recorded and transcribed for both research phases.

\subsection{Site selection criteria, data collection, and analysis}

The region of Tahoua (Fig. 2) is located in the central west of Niger, bordering the region of Agadez in the North, Nigeria in the South, and Mali in the West. The geographical features along the North to south axis of Tahoua change relative to the amount of rainfall. For instance, the South or agro-pastoral zone, with approximately $300-500 \mathrm{~mm}$ of rainfall per annum supports cultivation and is inhabited by primarily Hausa farmers, and the North with $100-300 \mathrm{~mm}$ is too marginal for farming and thus is mostly grasslands and inhabited by pastoralists of the Fulani and Tuareg cultural groups. Spatially based conflicts between pastoralists and agro-pastoralists over land tenure are endemic to the Tahoua region and vary in degree and typology along the north-south axis.

Site selection was based upon the following criteria: (1) multiple ethnic and cultural groups, (2) history of conflict between users, (3) existence of land use features of relevance such as seasonal lakes, enclosures, fields and possible man-made structures, (4) appropriate level of security for the research team and (5) availability of very high-resolution (VHR) imagery in satellite data archives. The total number by type of users (Table 1 ) was based upon the seasonal availability of actors in the zone. It is important to note that more pastoralists may have been present in the non-garden season between April and June, though the presence of gardeners and gardens would have been reduced during the data collection period (November and December 2015). During Phase 1, we conducted 9 focus groups (FG) in nomadic areas around Tillia and Droum with only pastoralists, and in Phase 2, we carried out a total of 19 individual interviews with pastoralists, gardeners and institutional actors. Individual gardeners were selected with the help of local informants using a 'snowball' or referral sampling process. Access to participants' gardens, grazing territories, or homes was gained through face-to-face, open discussions. The majority of individual interviews were conducted with only the participant, and the discussion focused on historical social and ecological changes, types and locations for institutional support, and the evolution of land and water access conflicts, using an interview guide to structure the conversation. All interviews were recorded with the permission of participants, and recordings were transcribed into French.

A preliminary inspection of available satellite images in Google Earth presumed the presence of physical enclosures in Tillia. Thereafter, VHR images from Quickbird-2 and WorldView-1 available in satellite data archives of the years 2003 and 2012 (Tillia) and 2004/05/06 and 2013 (Droum) were acquired. The VHR data served as a primary data source, supported by high-resolution (HR) optical satellite data from RapidEye (Table 2). The spatial resolution (pixel size) is typically between $0.5 \times 0.5 \mathrm{~m}$ and $1 \times 1 \mathrm{~m}$ for the VHR data with typically $10-15 \mathrm{~km}$ in swath width.

The applicability of the remote sensing change analysis depends on the availability of new (year 2012/2013) and archive data (going back to at least 2006). Archive images from before 2006 were available for only few areas in northern Tahoua, among them the regions around Tillia and Droum, for which also new imagery from 


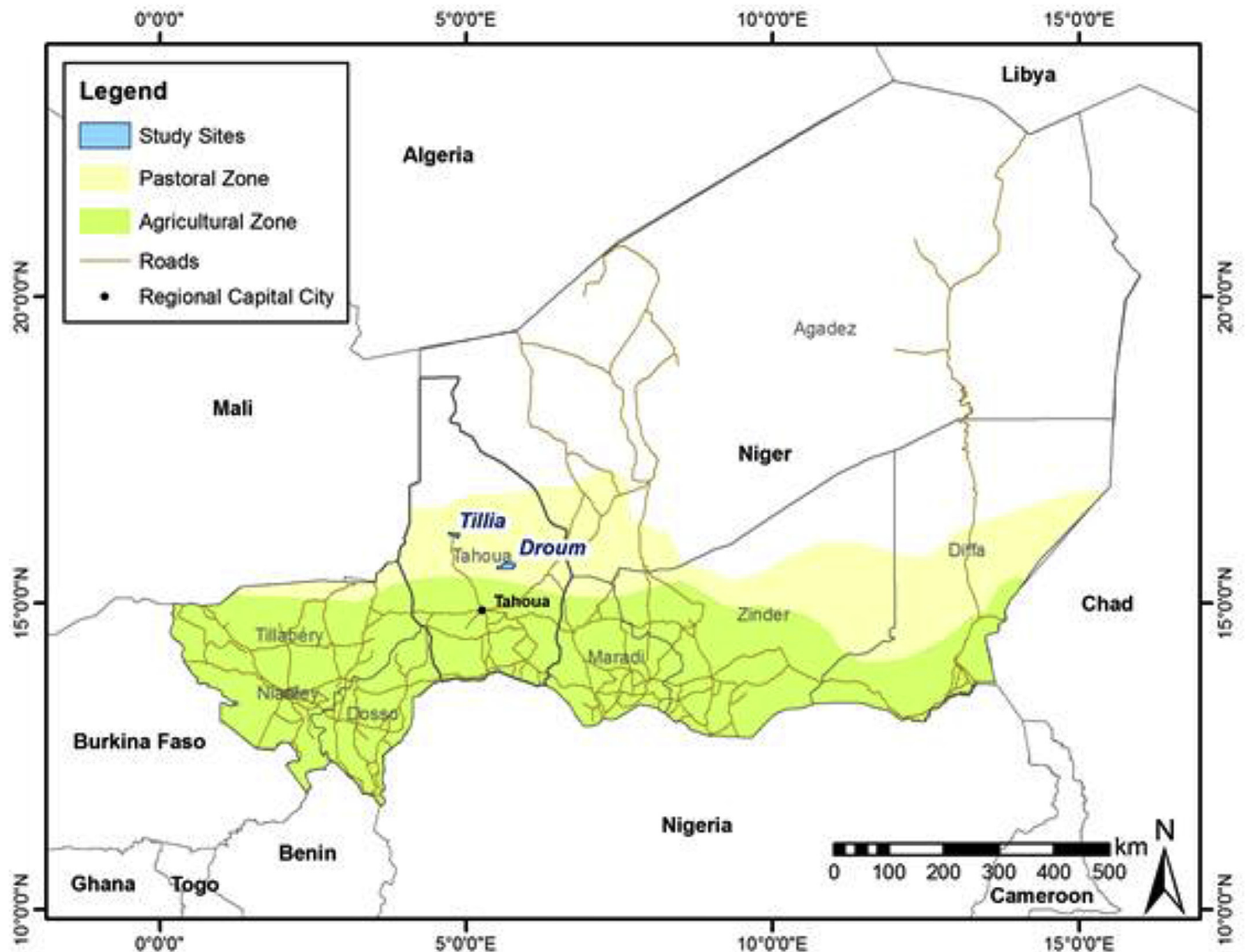

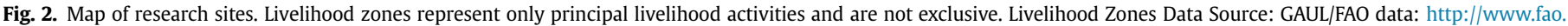
org/geonetwork/srv/en/metadata.show?id=12691, own figure.

Table 1

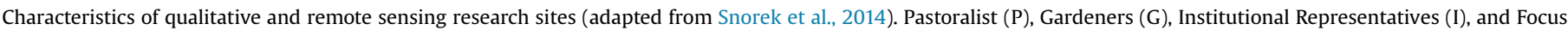
Groups (FG) Rainfall data: Climate Change Knowledge Portal (http://sdwebx.worldbank.org).

\begin{tabular}{|c|c|c|c|c|c|c|c|c|c|}
\hline $\begin{array}{l}\text { Village, } \\
\text { Commune }\end{array}$ & $\begin{array}{l}\text { Aver. Ann. } \\
\text { Rainfall } 1960 \\
\text {-1990 }\end{array}$ & $\begin{array}{l}\text { Aver. Ann. } \\
\text { Rainfall } 1990 \\
\text {-2012 }\end{array}$ & $\begin{array}{l}\text { \# Inter- } \\
\text { views \& FG }\end{array}$ & $\begin{array}{l}\text { \# Actors from } \\
\text { livelihood groups }\end{array}$ & $\begin{array}{l}\text { Major and } \\
\text { (minor) } \\
\text { ethnicities }\end{array}$ & $\begin{array}{l}\text { Presence of } \\
\text { cultivation }\end{array}$ & $\begin{array}{l}\text { Presence of } \\
\text { animal } \\
\text { corridor }\end{array}$ & $\begin{array}{l}\text { Seasonal lake } \\
\text { availability } \\
\text { (usage) }\end{array}$ & $\begin{array}{l}\text { Type of modern } \\
\text { water points }\end{array}$ \\
\hline Tillia, Tillia & $225 \mathrm{~mm}$ & $209 \mathrm{~mm}$ & $\begin{array}{l}10 \\
\text { interviews } \\
\text { (phase 2) }\end{array}$ & $\begin{array}{l}P(2) \\
G(6) \\
I(2)\end{array}$ & Tuareg (Fulani) & $\begin{array}{l}\text { Little to } \\
\text { none }\end{array}$ & Not relevant & $\begin{array}{l}\text { Yes (mostly } \\
\text { pastoral) }\end{array}$ & Lake, wells \\
\hline Droum, Kao & $267 \mathrm{~mm}$ & $244 \mathrm{~mm}$ & $\begin{array}{l}9 \text { interviews } \\
\text { (phase 2) }\end{array}$ & $\begin{array}{l}P(2) \\
G(5) \\
I(2)\end{array}$ & $\begin{array}{l}\text { Tuareg (Fulani, } \\
\text { Hausa) }\end{array}$ & Some & Yes & $\begin{array}{l}\text { Yes (mostly } \\
\text { gardening) }\end{array}$ & Lake, wells \\
\hline $\begin{array}{l}\text { Nomadic Camps } \\
\text { (Outside Tillia) }\end{array}$ & $225 \mathrm{~mm}$ & $209 \mathrm{~mm}$ & $\begin{array}{l}9 \text { FG (Phase } \\
\text { 1) }\end{array}$ & $\mathrm{P}(9)$ & $\begin{array}{l}\text { Tuareg (Fulani, } \\
\text { Arab) }\end{array}$ & None & Not relevant & $\begin{array}{l}\text { No (other water } \\
\text { sources) }\end{array}$ & $\begin{array}{l}\text { Borehole, deep } \\
\text { wells }\end{array}$ \\
\hline
\end{tabular}

2012 to 2013 was available (Table 2). Due to the large size of the Droum site three different image swaths had to be used. Archive images that were only available from different years (west: 2005, center: 2006, east: 2004) had to be combined and analyzed. Tillia was originally a site for the Phase 1 qualitative research, and Droum was added to compare the livelihoods in both zones of pastoral excellence.

\subsection{Data analysis}

Qualitative data was transcribed and literature, individual interviews, focus groups, and expert interviews were analyzed using AtlasTi 1.0.43 (AtlasTi $\mathrm{GmbH}$ ), a qualitative data analysis software that permits the codification, categorization, and synthesis of multiple types of data including images, text, pdfs, videos, and audio recordings. Primary categories analyzed for this paper 
include: perceptions of environmental change, changes to water and pasture access, historical events, conflict and cooperation, and divergent adaptations for multiple users.

The analysis was based upon two main actor groups: gardeners and pastoralists. These are defined as gardeners - typically sedentary, possessing a garden and also taking part in other livelihood activities (especially livestock rearing) and pastoralists - a livelihood and a socio-cultural group who use mobility in livestock rearing (but also possess territorial rights in local pastoral areas). Of the pastoral groups, the Tuareg historically maintained a caste system that further divided individuals into the servant or (formerly) slave caste, the blacksmith caste, and multiple scales of nobles and tribal leaders. Based on contemporary Tuareg cultural behavioral patterns, this study has focused on Tuareg noble (Imazawen) and servant (Eghawilen) castes.

In the visual analysis of satellite images, land features were identified and manually digitized as polygons using Geographic Information Systems (GIS) software. This was carried out for the two different time steps: archive images (2003-2006), and new images (2012-2013). Image pre-processing in terms of geometric correction, pan-sharpening (merging of panchromatic information in higher resolution with spectral information in lower resolution), spectral enhancement, and visualization as near infrared false color composite images were applied in order to provide best conditions for visual interpretation of land use features. These features are classified as follows: enclosures (closed fences) with or without cultivated fields inside (class 1 ), open enclosures such as broken or incomplete fences that may or may not contain cultivated fields (class 2), cultivated fields without enclosures (class 3), land and soil restoration features such as 'half-moons' and zai holes (class 4), settlements and dwellings (class 5), and seasonal lakes and wetlands (class 6). Using GIS techniques and spatial statistics a change detection approach was applied thereafter, revealing changes between the two different time steps. In these near infrared false color composites in Fig. 3 the appearance of the red color represents green vegetation and chlorophyll activity, and soil without green vegetation appears in colors from beige to grey and light blue.

\section{Results: enclosures in the pastoral zone of Niger}

\subsection{Social ecological history of Tillia and Droum's valley lakes}

The valleys of Tillia and Droum are refuges from drought and provide key water sources throughout the year. Their namesakes, as told by study participants, denote their geographical significance. Tillia, situated near the border of Mali, is an area that even today is considered a prime grassland 'reserve' due to great depth of the water table and the lack of hydraulic works. To exploit this zone, more well off pastoralists will fill cisterns on trucks and transport water to the areas of abundant pasture to give to their herds. Finding a water-rich valley in such a region, Tuareg herdsmen became so devoted to the place that they called it Tillia or 'I belong to her,' in Tamashaq. Droum, as perceived by the Tuareg, was a zone of special ecological richness (water, forest, pasture) and used primarily for pastoralism and as safe haven from drought. In the Tuareg's matrilineal culture, the women would have such an easy life in Droum, their plumpness would provoke 'tchideram' or stretch marks, from which Droum was derived.

According to research participants, the first gardens appeared in Tillia and Droum during and after several severe drought periods. In Tillia, gardens began after the second Great Drought in 1984-1985. In 2005, another drought period, a second valley southwest of Tillia (see inset of Fig. 4) began to be exploited for gardening. In Droum, former pastoralists first cultivated the land after the first big drought in 1973-74. When the second big drought occurred in 1984, customary and democratically elected leaders encouraged pastoralists in distress to cultivate gardens. Early gardeners were most likely to produce sorghum, cowpea, beans, tomatoes, watermelon, squash, and okra. Actors involved with these initial gardens were primarily former pastoralists, though others (primarily cultivators of the Hausa ethnic group) were attracted to the zone as well (Table 3). This creates multiple profiles for gardeners in the zone, disaggregated by time settled in the zone, time gardening, their former locations and activities, and diversification of activities (Table 3).

In recent times, the reasons and causes of cultivation of the valleys have shifted, as new actors and rules take precedence. In Tillia, according to the mayor, Tuareg groups make up 70\% of the population, Fulani 22\%, Hausa 6\% and Arab 2\% (P105). Locals account that there are many more Tuareg from the Eghawilen (former slave) group than Imazawagh (nobles) Tuareg in Tillia's gardens (Table 3). In Droum, the majority is also Eghawilen Tuareg, though there are about 200 individuals exploiting the garden area, including individuals from the Tuareg, Fulani, and Hausa ethnic groups. According to one Droum respondent, garden activities were not sustained by former pastoralists (Tuareg Imazawagh); however, southern cultivators (Hausa) and Eghawilen Tuareg stayed and occupied the land. The duration that gardens were being exploited varied from forty or more years (Droum) to less than one (Tillia). Reflecting the statement of one participant, the Hausa gardeners have had the longest tenure in garden work in the pastoral zone and the Eghawilen Tuareg are the most prevalent group of pastoralists-turned-gardeners.

\subsection{Evidence of increasing enclosures around lakes}

Garden cultivation and fencing of formerly pastoral territory is expanding geographically for both Droum (Kao Commune) and Tillia (Tillia Commune). Of the $81 \mathrm{~km}^{2}$ of pastoral (uncultivated) area in Tillia, areas surrounding ephemeral and permanent lakes are being fenced or transformed into fields (Table 4), yet the amount of fenced area increases significantly between the two

Table 2

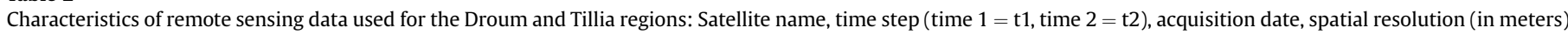
and spectral bands (blue $=\mathrm{B}$, green $=\mathrm{G}$, red $=\mathrm{R}$, near infrared $=\mathrm{NIR}$, and panchromatic $=$ pan).

\begin{tabular}{|c|c|c|c|c|c|}
\hline Village & Satellite & Time step & Acquisition date & Spatial resolution & Relevant spectral bands \\
\hline Droum & Quickbird-2 & $\mathrm{t} 1$ & 26 May 2004 & $0.6 \mathrm{~m}$ & $4(\mathrm{~B}, \mathrm{G}, \mathrm{R}, \mathrm{NIR})$ \\
\hline Droum & Quickbird-2 & $\mathrm{t} 1$ & 27 Jul 2005 & $0.6 \mathrm{~m}$ & $4(\mathrm{~B}, \mathrm{G}, \mathrm{R}, \mathrm{NIR})$ \\
\hline Droum & Quickbird-2 & $\mathrm{t} 1$ & 23 Feb 2006 & $0.6 \mathrm{~m}$ & $4(\mathrm{~B}, \mathrm{G}, \mathrm{R}, \mathrm{NIR})$ \\
\hline Droum & WorldView-1 & $\mathrm{t} 2$ & 05 Aug 2013 & $0.5 \mathrm{~m}$ & 1 (pan) \\
\hline Droum & WorldView-1 & $\mathrm{t} 2$ & 05 Aug 2013 & $0.5 \mathrm{~m}$ & 1 (pan) \\
\hline Droum & RapidEye & $\mathrm{t} 2$ & 19 Sep 2013 & $6.5 \mathrm{~m}$ & $5(\mathrm{~B}, \mathrm{G}, \mathrm{R}$, redEdge, NIR) \\
\hline Tillia & Quickbird-2 & $\mathrm{t} 1$ & 27 Sep 2003 & $0.6 \mathrm{~m}$ & $(\mathrm{~B}, \mathrm{G}, \mathrm{R}, \mathrm{NIR})$ \\
\hline Tillia & Quickbird-2 & $\mathrm{t} 2$ & 12 Dec 2012 & $0.6 \mathrm{~m}$ & (B, G, R, NIR) \\
\hline
\end{tabular}



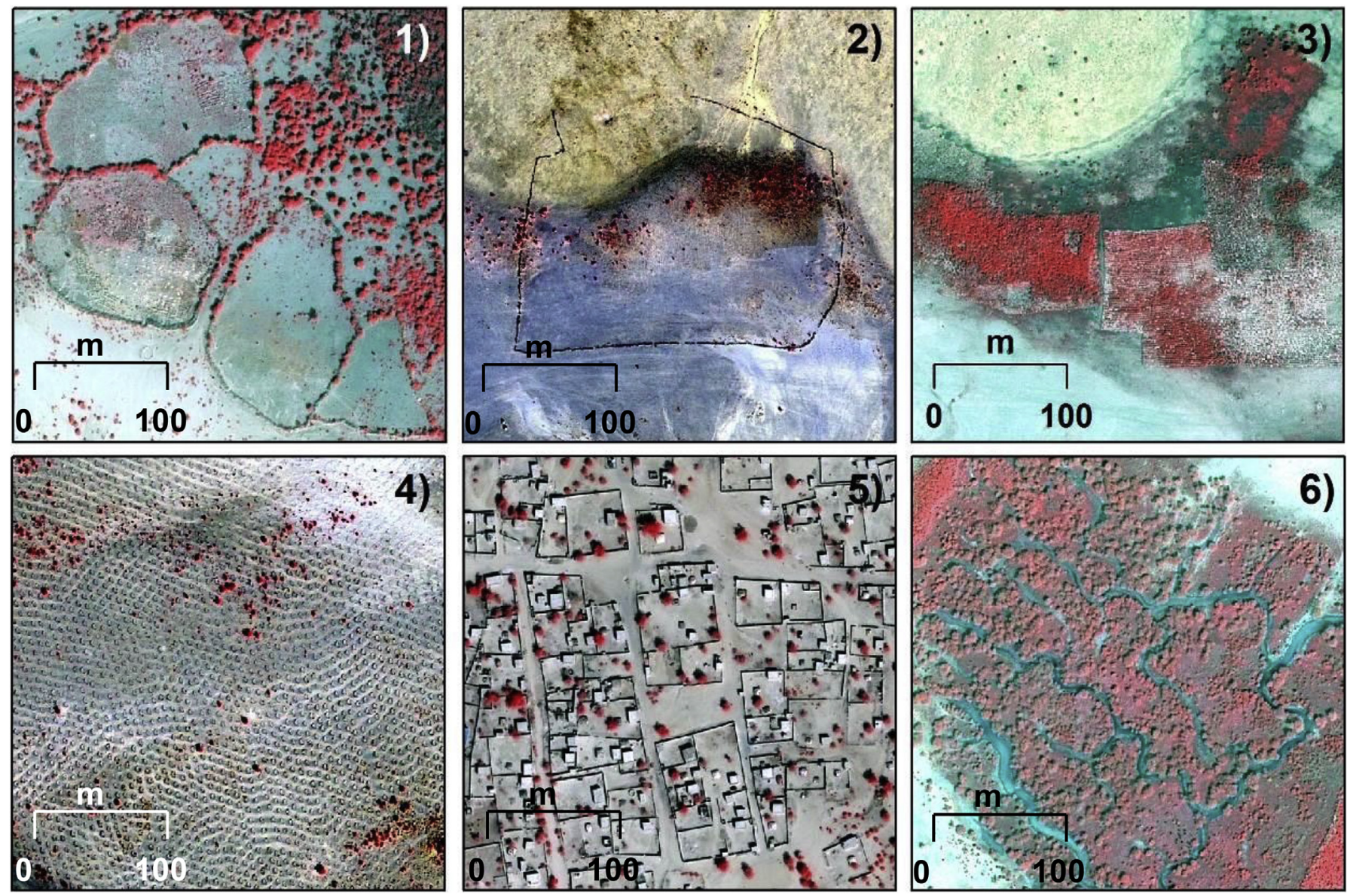

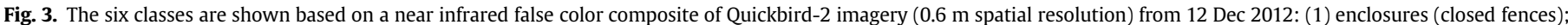
(2) open fences; (3) cultivated fields without enclosures; (4) land restoration features; (5) settlements; (6) seasonal lakes and wetlands; Source: Quickbird-2 @DigitalGlobe.

periods of analysis. Closed fences examined using remote sensing of Tillia (Fig. 4), increased by almost 102\% in 2012 with respect to the closed fence area in the archive image in 2003, corresponding to a change from approximately $1 \mathrm{~km}^{2}$ (2003) to $2 \mathrm{~km}^{2}$ (2012) of enclosed area (Table 4). The area of open fences, which we determined represents claimed territory that may or may not be cultivated, increased by $147 \%$, whereas the area of cultivated fields without fences decreased by $-88 \%$.

The most significant land use/land cover changes in Tillia were a conversion of previously uncultivated land into areas of closed fences $\left(1.1 \mathrm{~km}^{2}\right)$ as well as open fences $\left(0.8 \mathrm{~km}^{2}\right)$. Concurrently, a shift from closed $\left(0.45 \mathrm{~km}^{2}\right)$ and open fences $\left(0.3 \mathrm{~km}^{2}\right)$ towards uncultivated land took place. This shift, while not specifically analyzed in the qualitative research is most likely related to the shifting nature of land tenure claims and land tenure disputes in the pastoral region. Further study would be needed to understand the range of land tenure dynamics taking place. The strong loss of cultivated fields without fences can be explained by a conversation into uncultivated land $\left(0.6 \mathrm{~km}^{2}\right)$ and a shift towards closed $\left(0.35 \mathrm{~km}^{2}\right)$ and open fences $\left(0.2 \mathrm{~km}^{2}\right)$. The latter is clearly depicted in the inlet in Fig. 4. These changes exemplify potential shifts in land use and access regimes, which were explored further in the individual interviews. Significant areas (41\%) have been restored through land management projects such as digging water-holding trenches and planting trees, activities that may preclude cultivation.

The settled parcels of the town of Tillia increased by $39 \%$ within the 9-year period, and the number of single dwellings (Fig. 4) scattered around the area increased by $129 \%$ (Table 4). In 2012, new settlements southeast of Tillia were detected, which are in the vicinity of new fences. In this same area, open cultivated fields (inset, Fig. 4) transformed into fenced areas (green), which is reflected by the decrease of cultivated open area, and increase of closed and open fences (Table 4).

The second study site located northwest of Kao, called Droum consisted of $263 \mathrm{~km}^{2}$ of total space analyzed, which is three times larger than the Tillia site. Within Droum, there was a $124 \%$ increase of closed fences between 2004/05/06 and 2013, a change from $4.71 \mathrm{~km}^{2}$ to $10.58 \mathrm{~km}^{2}$, and an increase in number or count of fences (features) by $176 \%$ (Table 5). Most of these stretch around the contour of the wetlands. The strong increase of open fences by more than $300 \%$ is mostly due to one very large area that has been fenced on the east of the study site (Fig. 5). The total area of open fields remained the same, but there were many changes in the locations of the fields. The total settlement area increased by $39 \%$ and the number of single dwellings by $47 \%$.

In Droum, closed fences $\left(2 \mathrm{~km}^{2}\right)$ and open fences $\left(0.75 \mathrm{~km}^{2}\right)$ remained unchanged, whereas a conversion of uncultivated land towards closed fences $\left(7.5 \mathrm{~km}^{2}\right)$ and open fences $\left(11.5 \mathrm{~km}^{2}\right)$ occurred, which can be seen in the central and eastern part of Droum in Fig. $5.1 \mathrm{~km}^{2}$ of open fences was transformed into closed fences. Large areas of cultivated fields without fences remained stable $\left(1.05 \mathrm{~km}^{2}\right)$, and there have been significant change dynamics from cultivated fields without fences to uncultivated land $\left(6 \mathrm{~km}^{2}\right)$ and vice versa $\left(4 \mathrm{~km}^{2}\right)$, only a smaller area of fields $\left(0.75 \mathrm{~km}^{2}\right)$ shifted towards open fences. 


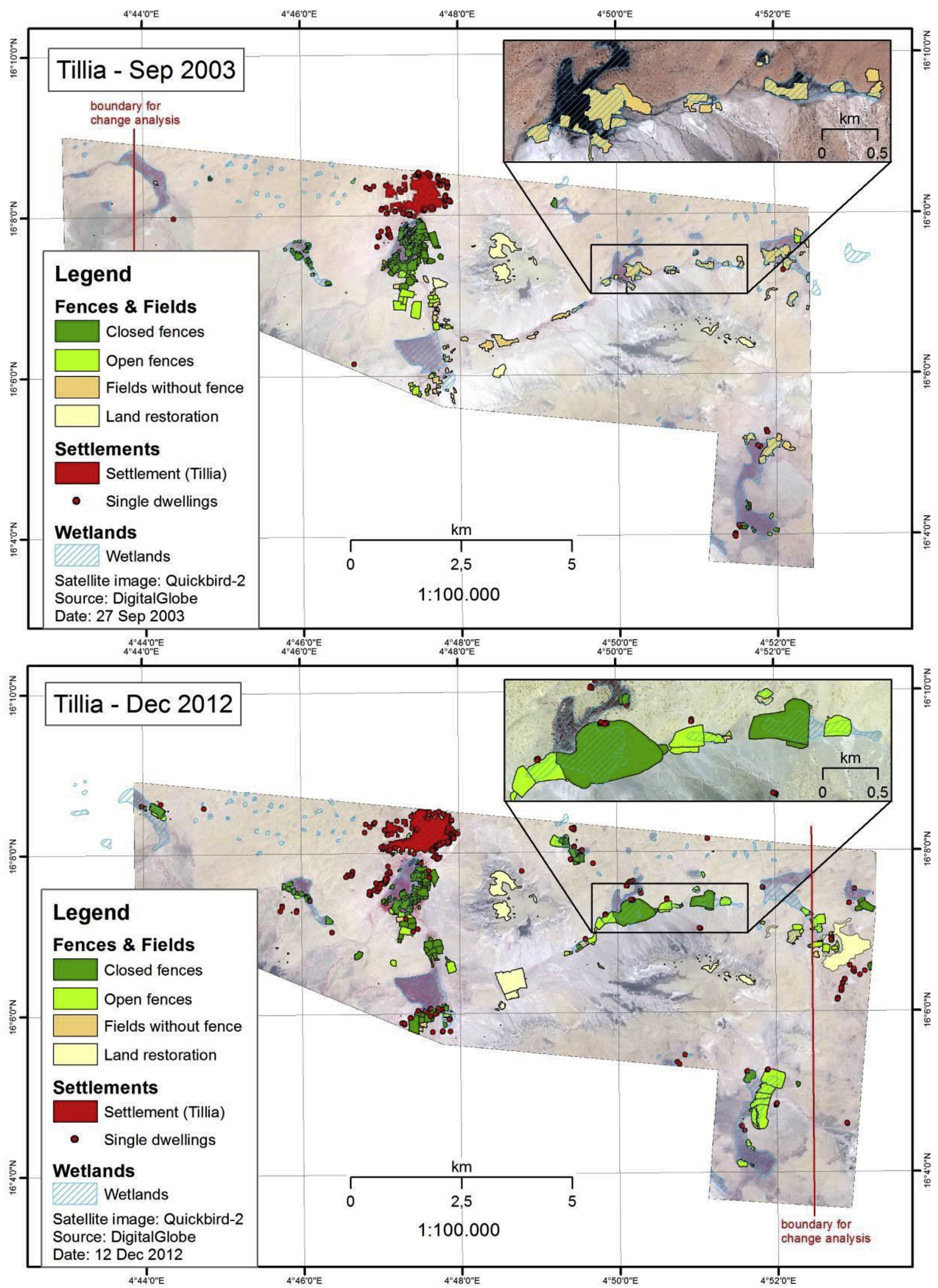

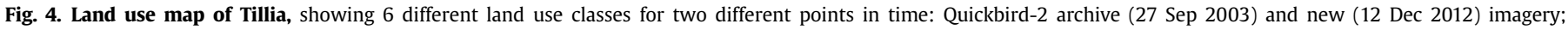
background is uncultivated space. A newly cultivated valley in the east of Tillia is displayed in the inset. Image source: Quickbird-2 0 DigitalGlobe. 
Table 3

Characteristics of gardeners in Tillia and Droum. Numbers indicate the number of participants that mentioned the statement in the left-most column based on qualitative, guided questionnaires, organized by actor category. Second-row abbreviations indicate ethnic groups: H (Hausa), F (Fulani), TE (Tuareg Eghawilen), TI (Tuareg Imazawen).

\begin{tabular}{|c|c|c|c|c|c|c|c|c|}
\hline \multirow[t]{3}{*}{ Characteristics of gardeners } & \multicolumn{4}{|c|}{ Tillia } & \multicolumn{4}{|c|}{ Droum } \\
\hline & \multicolumn{4}{|c|}{ Gardener (6) } & \multicolumn{4}{|c|}{ Gardener (5) } \\
\hline & $\mathrm{H}$ & $\mathrm{F}$ & $\mathrm{TE}$ & TI & $\mathrm{H}$ & $\mathrm{F}$ & TE & $\mathrm{TI}$ \\
\hline Pastoralist became gardener & 0 & 1 & 3 & 0 & 0 & 1 & 1 & 1 \\
\hline Gardener owns livestock & 0 & 1 & 1 & 0 & 2 & 1 & 0 & 2 \\
\hline Actor moved North to garden & 2 & 1 & 0 & 0 & 1 & 0 & 0 & 0 \\
\hline Time Gardening: 40 years & 0 & 0 & 0 & 0 & 0 & 0 & 0 & 1 \\
\hline Time Gardening: $10-40$ years & 0 & 0 & 0 & 0 & 1 & 1 & 0 & 0 \\
\hline Time Gardening: $<$ or $=10$ years & 2 & 0 & 2 & 0 & 0 & 0 & 1 & 0 \\
\hline Time in situ: $30+$ years & 2 & 0 & 0 & 0 & 2 & 0 & 0 & 1 \\
\hline Time in situ: $1-30$ years & 0 & 0 & 0 & 0 & 0 & 0 & 0 & 1 \\
\hline Time in situ: $<1$ year & 0 & 2 & 0 & 0 & 0 & 0 & 0 & 0 \\
\hline
\end{tabular}

The four classes: enclosures (closed fences), open fences, land restoration features, and settlements were reliably detectable and visually interpreted in all VHR images independent of seasonal dynamics. Enclosures and fences created by thorny branches show low reflectance with respect to other land cover in all image bands, which made them easily detectable. Enclosures can also contain high near infrared reflection in case they are vegetated, which results in a high contrast to the surrounding land (Fig. 3). Interpretation errors are more possible for cultivated fields without enclosures, since fields are better detected during the growing season, for which VHR images were not always available (Table 2). This class was mapped in addition to enclosures, and is not of particular focus in this study. Seasonal lakes and wetlands are very dynamic due to seasonal variations in their extent and would require inter-annual time series of satellite imagery. Since VHR data at different time steps is limited, only one wetland mask was created from multi-temporal VHR images in combination with a Landsat 8 image from the rainy season 2013.

\subsection{Outsiders cultivating the commons}

While the majority of gardeners are former pastoralists who are indigenous to the zone, it is also highly attractive for outside groups to take up subsistence farming. Four cases of gardeners emigrated to the Tillia and Droum from elsewhere (Participants 76, 81, 110, 111). All of the gardeners but Participant 111 settled in their respective areas more than 30 years prior (1984/85). A Fulani gardener (111) arrived less than a year ago from Dogon Doutchi (a small town in southern Niger). Participant 111 was raised in pastoralism, yet he no longer had livestock and was seeking land. Of the three Hausa participants, all had spent more than 30 years in the zone; two of them came as children with their fathers, who engaged in small business activities such as selling sugar, tea, and tobacco to pastoralists. The Droum gardener (76) came with his family due to the fact that there was no more exploitable land and very few trees (for wood sales) in Tamaske, his home village. Two gardeners (76 and 81 ) perceived that cultivation is the modus operandi to develop the pastoral zone, and one (76) referred to president Kuncé's "land to the tiller" speech from 1974 (Table 6) as part of the reason he was permitted to cultivate in the North. The Fulani (111) who emigrated from outside the pastoral zone tended to base his decisions for land tenure and settlement on the level of social capital with current gardeners or administrators.

\subsection{The pastoral zone's fuzzy land tenure rules}

Despite the perception that land can be claimed by any able cultivator (a phenomenon in both the agricultural and pastoral zones), the formalization of ownership and the right to sell the land expressed contradictions. Respondents recognize priority rights of the indigenous pastoral groups and perceive that it is the pastoral zone. Yet, there were multiple interpretations of how the common zone should be used and by whom. Some stated that the pastoral space belonged to the pastoral groups who have possessed home territories in the zone for centuries (primarily of the Tuareg Imazawagh), yet concurrently recognized norms in place granting ownership to cultivators, stemming from the "land to the tiller"

Table 4

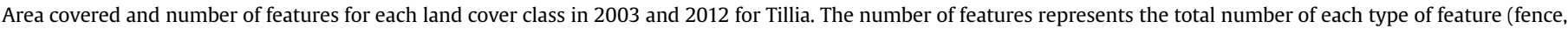
land restoration, settlement, dwelling). Not applicable data is marked as "n/a".

\begin{tabular}{|c|c|c|c|c|c|c|c|c|}
\hline \multirow[t]{2}{*}{ TILLIA 2003-2012 } & \multicolumn{4}{|c|}{ AREA $\left[\mathrm{km}^{2}\right]$} & \multicolumn{4}{|c|}{ NUMBER OF FEATURES [count] } \\
\hline & $\begin{array}{l}2003 \\
{\left[\mathrm{~km}^{2}\right]}\end{array}$ & $\begin{array}{l}2012 \\
{\left[\mathrm{~km}^{2}\right]}\end{array}$ & $\begin{array}{l}\text { change } \\
{\left[\mathrm{km}^{2}\right]}\end{array}$ & $\begin{array}{l}\text { change } \\
{[\%]}\end{array}$ & $\begin{array}{l}2003 \\
\text { [count] }\end{array}$ & $\begin{array}{l}2012 \\
\text { [count] }\end{array}$ & $\begin{array}{l}\text { Change } \\
\text { [count] }\end{array}$ & $\begin{array}{l}\text { change } \\
{[\%]}\end{array}$ \\
\hline Closed fences & 1.03 & 2.08 & 1.05 & $101.9 \%$ & 172 & 219 & 47 & $27.3 \%$ \\
\hline Open fences & 0.48 & 1.18 & 0.70 & $147.1 \%$ & 48 & 56 & 8 & $16.7 \%$ \\
\hline Fields without fence & 1.27 & 0.15 & -1.12 & $-88.0 \%$ & 64 & 12 & -52 & $-81.3 \%$ \\
\hline Land restoration & 0.55 & 0.77 & 0.23 & $41.1 \%$ & 33 & 42 & 9 & $27.3 \%$ \\
\hline Settlements (Tillia) & 0.63 & 0.87 & 0.25 & $39.0 \%$ & $\mathrm{n} / \mathrm{a}$ & $\mathrm{n} / \mathrm{a}$ & $\mathrm{n} / \mathrm{a}$ & $\mathrm{n} / \mathrm{a}$ \\
\hline Dwellings (SW Tillia) & $\mathrm{n} / \mathrm{a}$ & $\mathrm{n} / \mathrm{a}$ & $\mathrm{n} / \mathrm{a}$ & $\mathrm{n} / \mathrm{a}$ & 125 & 286 & 161 & $128.8 \%$ \\
\hline
\end{tabular}

Table 5

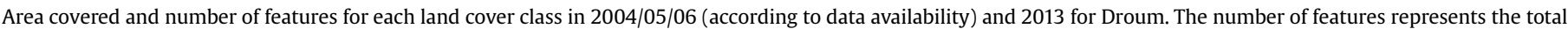
number of each type of feature (fence, land restoration, settlement, dwelling). Not applicable data is marked as "n/a".

\begin{tabular}{|c|c|c|c|c|c|c|c|c|}
\hline \multirow[t]{2}{*}{ DROUM (KAO) 2004/05/06 - 2013} & \multicolumn{4}{|l|}{ AREA $\left[\mathrm{km}^{2}\right]$} & \multicolumn{4}{|c|}{ NUMBER OF FEATURES [count] } \\
\hline & $\begin{array}{l}2004 / 05 / 06 \\
{\left[\mathrm{~km}^{2}\right]}\end{array}$ & $\begin{array}{l}2013 \\
{\left[\mathrm{~km}^{2}\right]}\end{array}$ & $\begin{array}{l}\text { Change } \\
{\left[\mathrm{km}^{2}\right]}\end{array}$ & $\begin{array}{l}\text { Change } \\
{[\%]}\end{array}$ & $\begin{array}{l}2004 / 05 / 06 \\
\text { [count] }\end{array}$ & $\begin{array}{l}2013 \\
\text { [count] }\end{array}$ & $\begin{array}{l}\text { Change } \\
\text { [count] }\end{array}$ & $\begin{array}{l}\text { Change } \\
\text { [\%] }\end{array}$ \\
\hline closed fence & 4.71 & 10.58 & 5.86 & $124.2 \%$ & 226 & 625 & 399 & $176.6 \%$ \\
\hline open fence & 3.17 & 13.07 & 9.89 & $312.0 \%$ & 80 & 73 & -7 & $-8.8 \%$ \\
\hline field without fence & 17.14 & 15.02 & -2.13 & $-12.4 \%$ & 71 & 113 & 42 & $59.2 \%$ \\
\hline Land restoration & 2.73 & 3.29 & 0.55 & $20.1 \%$ & 13 & 20 & 7 & $53.9 \%$ \\
\hline Settlements & 0.58 & 0.81 & 0.23 & $39.9 \%$ & 225 & 791 & 566 & $251.6 \%$ \\
\hline Dwellings & $\mathrm{n} / \mathrm{a}$ & $\mathrm{n} / \mathrm{a}$ & $\mathrm{n} / \mathrm{a}$ & $\mathrm{n} / \mathrm{a}$ & 580 & 854 & 274 & $47.3 \%$ \\
\hline
\end{tabular}



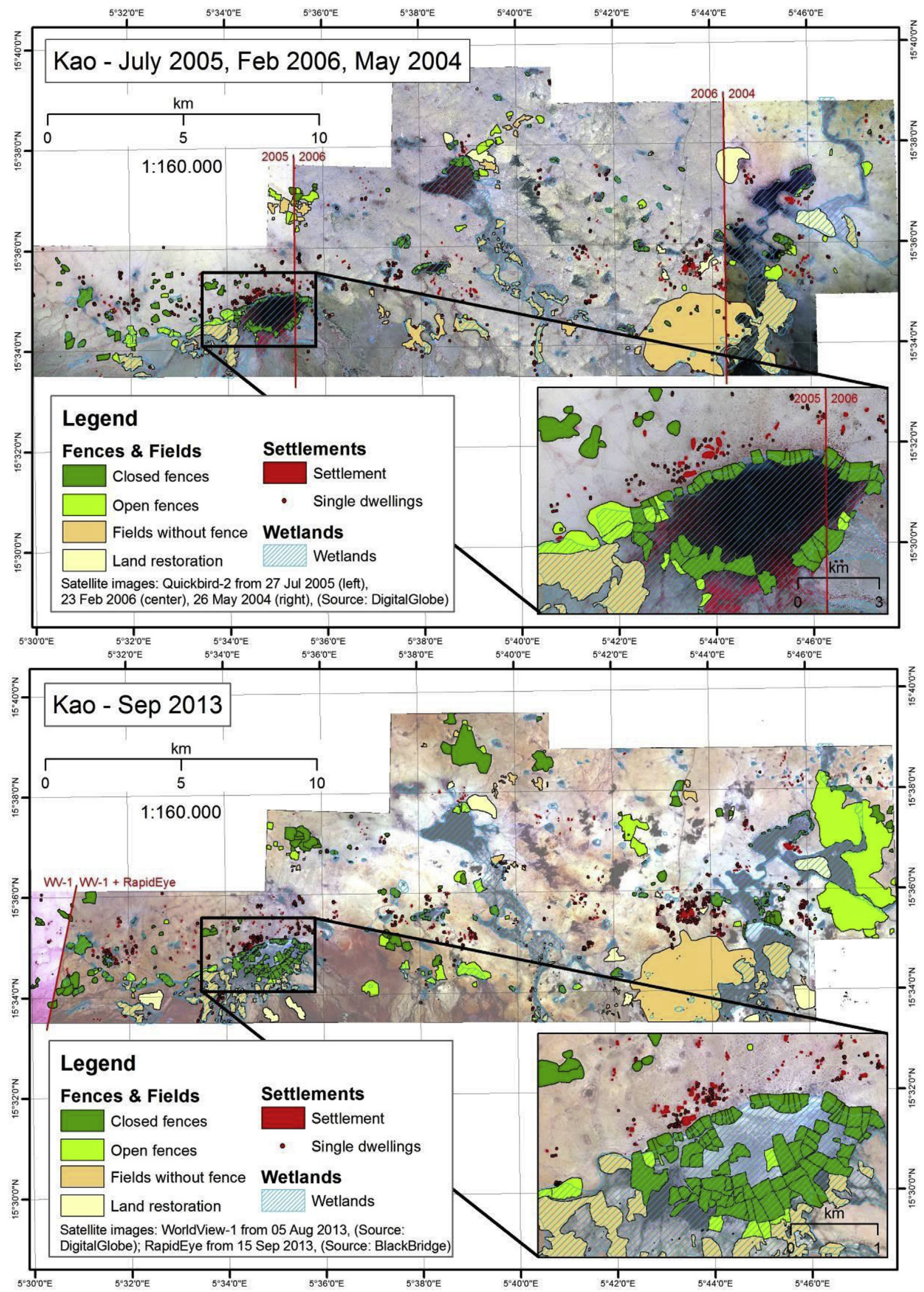

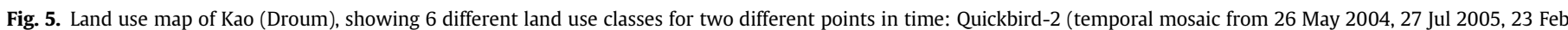

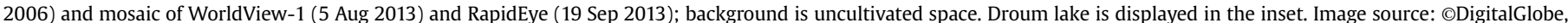
@BlackBridge. 
Table 6

Perceptions based on "Land to the Tiller" speech of 1974.

\begin{tabular}{|c|c|}
\hline Actor (Locale) & Quotes expressing local perceptions of "Land to the Tiller" \\
\hline Hausa Gardener (Tillia) & ce 1984 , we earned the right to authorize each person to look for places in the valleys where we can exercise our agriculture activities. \\
\hline $\begin{array}{l}\text { Tuareg Eghawilen Gardener } \\
\text { (Tillia) }\end{array}$ & $\begin{array}{l}\text { Since each person can take land as he wishes, I also took mine; I fenced it so it became my plot. Before, this place was full of trees, which I cut } \\
\text { to transform it into a garden. }\end{array}$ \\
\hline $\begin{array}{l}\text { Tuareg Eghawilen Gardener } \\
\text { (Tillia) }\end{array}$ & No one gave the land to me. When I arrived, it had never been cultivated. I prepared the land. \\
\hline $\begin{array}{l}\text { Administrator (Droum) } \\
\text { Hausa Gardener (Droum) }\end{array}$ & $\begin{array}{l}\text { They [outsiders] have water [in the South] but barely a few meters squared [of land]. And here, one can claim a hectare ... or even two! } \\
\text { (Why did you come here from Tamaské?) It's because of agriculture. (So, there isn't space in Tamaské?) Right, the space is crowded, } \\
\text { insufficient. }\end{array}$ \\
\hline
\end{tabular}
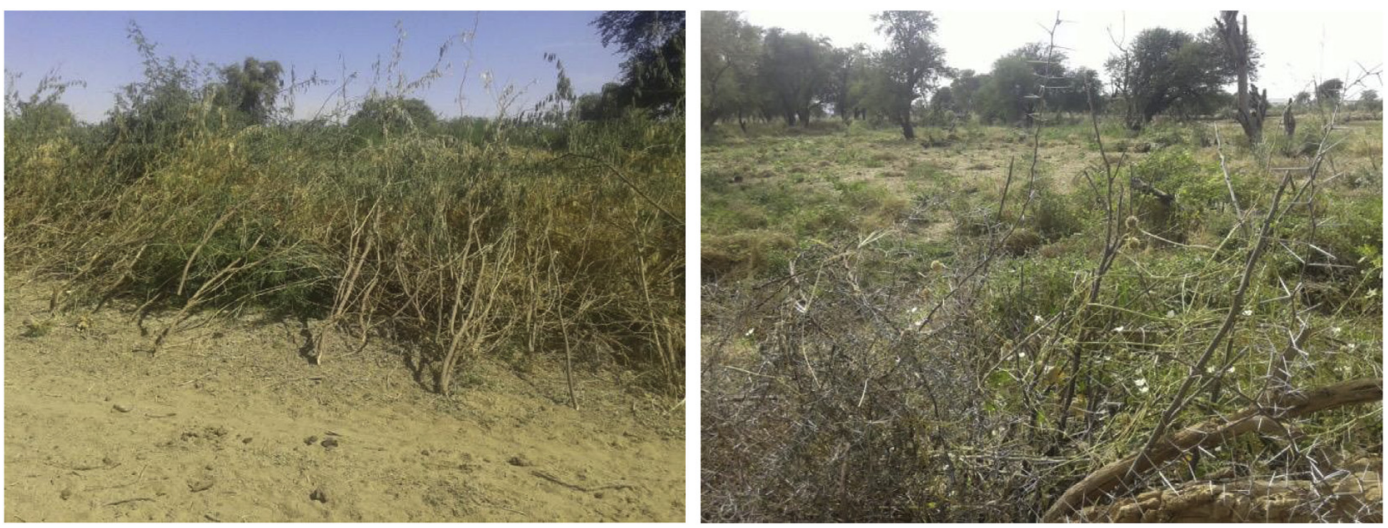

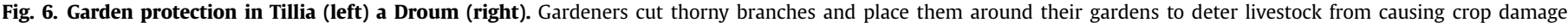
(Author's photo, Tillia and Droum, Nov 2015).

speech as well as adaptation policies of 1984 .

Multiple administrative officials (including one representative of land commissions) made statements that land titles are not available to individuals in the pastoral zone, implying that one cannot sell land and upholding the Law of 1961 that allowed only subsistence farming in cases of vulnerability. "The land commission does not have the right to deliver land titles ... but there are agreements that can be made with customary chiefs to enable one to exploit the land" (P105). The 1961 law permits the establishment of oasis gardens, which in turn would grant rights to land titles for this purpose.

"The pastoral space, we say that it is for them [pastoralists], but agriculturalists take more advantage of it" (personal communication, P112 Expert Droum).

"I have said that the fact of putting fields in the pastoralists' spaces is disparaging because, the disparagement is derived from the fact one is finding and installing something in a space that does not belong to him. However, there is a policy in place, following the [drought] ... that pushes those who no longer have livestock (vulnerable) to make gardens" (personal communication, P77 Gardener Droum).

Seven respondents ( 5 in Droum and 2 in Tillia) explained that they obtained land through purchase, even outsiders (Table 6). Still two others ( 1 in Droum and 1 in Tillia) mentioned to have received land titles from the land commission during time when Tandja was governor of Tahoua (1981-1988), a practice that is now officially forbidden, yet land sales show evidence of a private regime.

\subsection{Gardening to receive project aid}

During an interview in Niamey in November 2010, the representative to the minister of Niger's Ministry of Water, Environment, and the Fight against Desertification stated that: "He who is sitting on water need not be thirsty," and another technical assistant in the same ministry mentioned that only $1 \%$ of Niger's surface water was being exploited (personal communication, Oct 2010, Niamey). Since 2003 , the country's adaptation policy has focused on improving the exploitation and utilization of ephemeral and permanent lakes and ponds for food production.

Multiple projects (NGOs cited include: EIRENE, AdKool, Aharog) have responded by cultivating the valleys in Droum and Tillia, prompting an acceptance of pastoral zone cultivation and a rush to receive lucrative support from government and non-government actors and to legitimately claim the public land through garden development. Twenty years ago, project aid supported the adaptation of former pastoralists into sedentary livelihoods; those with gardens "received a bit more than those who did not [cultivate]" (P112). According to the institutional actors in Tillia, specific garden aid arrived in Tillia beginning in 2002 with support from an international non-governmental organization (NGO). In Droum, an international NGO is installing (at no cost) ten trial drip irrigation systems for selected gardeners (P77). Pastoralists expressed more frustration and uncertainty about available aid, stating that it was only given to sedentary households and that some gardeners strategically exploit gardens to receive aid.

"[Cultivators] ... hope also to have project aide [from their gardens]. (Projects help them?) It is what we hear. They receive sacks of millet during the rainy season. (So, they seek aid through their cultivation?) That's right, because we haven't seen 
someone who spent the year eating his harvest production" (personal communication, P14 Tillia Pastoralist).

Project aid is a lucrative benefit for gardeners. Along with NGO aid, the government distributes complimentary seeds on a yearly basis for cultivation in both Tillia and Droum. Types of cultivationbased governmental/non-governmental aid cited include: donkey carts, motor-pumps, water piping, seeds, watering cans, wells, and subsidized fodder.

“... It is normal [to cultivate in the pastoral zone] ... because the authorities have given us permission. At present, in the city, there is an agriculture agent that the State sent here ... Also, the State provides seeds ... if the State has authorized it, it is normal" (personal communication, P110 Hausa Gardener Tillia).

Very few pastoralists stated that they had received aid; recipients cited such aid as animal fodder, grain, medicine, and hydraulic infrastructure from NGOs (namely NGOs Amman Imman and EIRENE). Government livestock services charge fees for livestock treatments (not for vaccinations, which are free). Pastoralists receiving support to rebuild a modern well estimated paying up to 300,000 FCFA. Contrariwise, gardeners receiving generators and water infrastructure paid no compensation. The distribution of project aid is a normative force framing the development of the pastoral zone.

\subsection{Build a fence, sell water access}

Fencing is the main requirement for a successful garden venture in the pastoral zone. As observed in both Tillia and Kao (Droum) (Figs. 4 and 5), fenced-in garden plots have colonized the valley. The temporal and spatial changes occurring in both Tillia and Droum have impacted water access for non-gardener actors (pastoralists, brick-makers, households gathering water). Fig. 6 shows fences made of thorny branches that are visible as linear structures in the satellite images.

In 2003, the land commission (commission foncière) was established in Droum in order to organize the rural space and maintain peace and security for all users. Despite over 10 years working in Droum, users in Droum expressed multiple conflicts related to water access, livestock corridors, alternative water facilities (wells, boreholes), costs of water and crop or livestock damage, excessive wood cutting, and dangerous access points for livestock (Fig. 7). Overall, the mechanisms for compensation benefit only landholders, who are also able to exclude livestock and privatize the land in Droum, actions equivalent to the southern private land regimes (Snorek et al., 2014). Pastoralists in Droum frequently pay damages to gardeners, sometimes with the lives of their animals, who are violently chased out of the space.

In Droum, temporal and spatial constraints limit livestock access, especially during the end of the gardening period, which coincides with the hot period of the year when livestock are heavily demanding water (March and April). Strong fencing activities as visible in the satellite images in Fig. 7 (inset: Droum lake) imply restricted water access for livestock. Gardeners refuse access and have closed certain corridors in order to protect their garden produce. These acts are contrary to the government's rules of water access (article 25 de l'ordonnance $\mathrm{n}^{\circ}$ 2010-029), yet enforcement is lacking. Pastoralists feel unable to discuss these problems openly (P116 and P118) and have been turned away by local and subnational institutional actors. Livestock, in turn, are forced to pass into areas that are narrow and dangerous due to thick mud and sinkholes (Fig. 7, right), leading one pastoralist to state that gardeners are, “... hoping for the misfortune of pastoralists” (P108).

Gardeners have begun to commercialize lake water, which provides a safe and sufficient option for pastoralists' livestock. Using pumps received from project aid for its distribution, gardeners sold water for as much as 10,000 to 15,000 FCFA per herd, variable based on the number of animals. This serves as a sure source of revenue for gardeners during the long dry season, though land commissions and pastoralists are condemning this practice.

"The gardeners stated - we will never open here [the livestock corridor] ... on the other side [of the lake], it is mud, but the cows are obliged to drink there ... or they will pay money [to the gardeners] ... they are preventing livestock access completely during the months of March and April." (Administrator Droum).

"\{Gardeners $\}$ are beneficiaries of a motor-pump and sell water to the pastoralists ... for each passage of an animal next to his so-called garden" (Pastoralist from Droum).

Leaders in Droum stated openly that they cannot uphold natural resource management plans. Gardeners act with impunity, closing government-arranged corridors to suit their livelihood activities. These perceptions provoke conflict between gardeners and pastoralists; many sedentary actors (gardeners and institutions - P115, P118, P77, P116) expressed sympathy for pastoralists who are unable to exploit "their own territory" (P115).

Tillia, on the contrary, upholds a more equitable system and organization of the rural geographical space. As explained by the mayor of Tillia, conflicts occur around man-made water
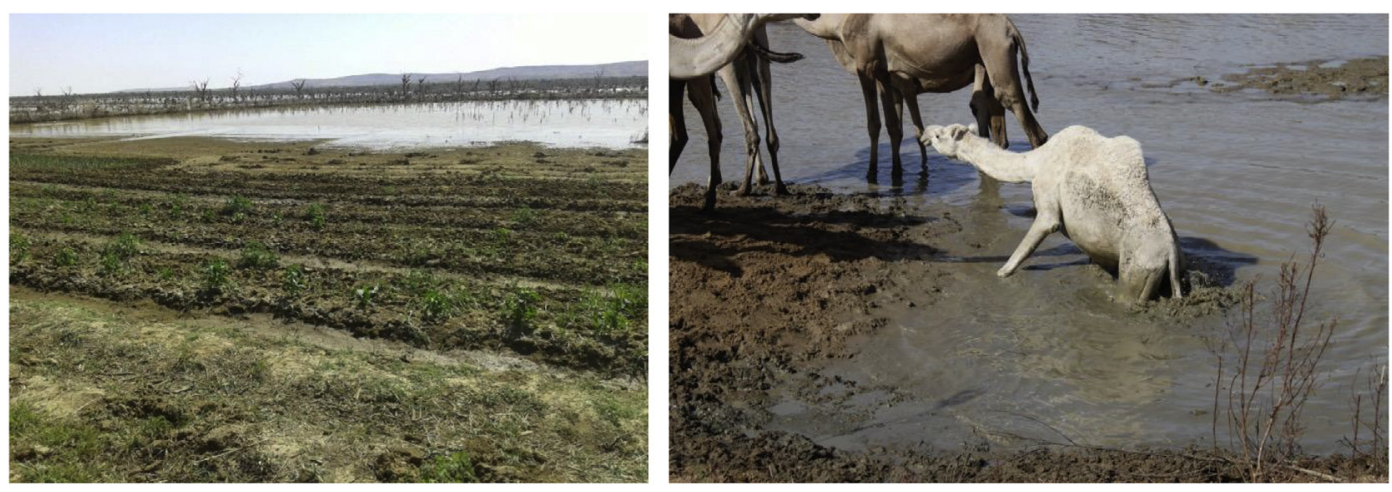

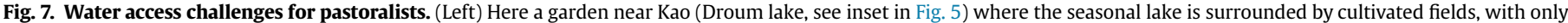

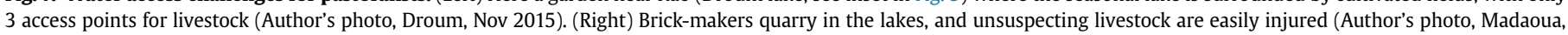
Dec 2011). 
infrastructure in Tillia, due to their rarity and cost. Lakes are a free, open source of water for multiple pastoral groups - visiting herders and local pastoralists (Table 7). Visiting herders complain about the long wait times at boreholes and the lack of priority use, which sometimes provokes conflicts. The taxing of livestock owners for crop damage is unfeasible in Tillia, rather gardeners complained that about their inability to receive payment for damages to their crops. Both livestock and gardens must be guarded by their proprietors, promoting greater cooperation and prevention amongst users. The entire northern part of the lake is open for livestock access, and cultivation is only possible in small plots in the South. There are, as a result fewer conflicts in Tillia at the garden site resulting from lake water access. Conflicts in Tillia commence upon the desiccation of the lake (March/April), when reliance on hydraulic infrastructure increases.

\section{Discussion: gardening as divergent adaptation in the pastoral zone}

It is indisputable that irrigated 'oasis' garden activities are an essential 'adaptation' for both pastoral and gardener groups, and also gardens have the potential to be a divergent adaptation without proper commons management. Niger's pastoral zone has for centuries been managed through common pool regime norms (see also Ostrom, 1999) to maintain the ecological limits of the pasture, the cultural and familial connectivity of pastoral groups, and the reciprocity between groups in times of drought or crisis. Yet, with increasingly difficult social and ecological shifts (Snorek et al., 2014), sedentarization is becoming a predominant adaptation in the zone, and this pattern tends to usurp commons regimes through privatization and commodification. Water, an essential and strategic resource for the multiple actors presented in this case is being enclosed through gardening activities, in order to protect garden production from livestock damage. Though gardeners' production is protected by both legislation and local norms, water access must concurrently be made available to pastoral groups in order to prevent conflicts. Three concurrent dynamics that have prompted more divergent adaptation in the social ecological system are relevant to these cases of rapid expansion of gardening in the pastoral zone: 1) differential land tenure norms and expectations (shared by both pastoralists and gardeners) 2) the loss of the respect for and management of common pool resources, and 3) the commodification of land and water pastoral resources.

Niger's government, has developed legislation and policy documents to prevent the enclosure of pastoral resources in the northern pastoral zone (see Snorek et al., 2014). On 23 February 2015, the Office of the Prime Minister established a committee made up of representatives and directors from all of the government bodies concerned with the practice of livestock rearing and pastoralism (Arrété N0016/PM/SGG of 23 Feb 2015) with the stated purpose to instruct and propose to the government of Niger how to solve the problem of increasing occupation and privatization of pastoral space. The official document reiterates that the following acts are unauthorized: limiting of pastoralists' access to pastoral resources north of the limit to cultivation (without State and community approval) and "the individual appropriation as a way to indiscriminately and privately control public water points" (Snorek et al., 2014). According to the mayor of Abalak (a town southeast of Tillia within the pastoral zone), none of the local administrators have yet been approached to discuss the problems of land appropriation. This in-action, he stated, "is due to perceptions of the intractability of the problem" (personal communication with Mayor of Abalak, November 2015).

Gardening is a divergent adaptation where it reduces the adaptive capacities of some users over other users. Within the context of Droum, the 'losers' in this divergent adaptation are inevitably pastoral users of the water, as the costs for access have increased through fees, dangerous access points, and harm to livestock who are chased away by gardeners (Table 7). Gardeners in Tillia, contrariwise, must guard their fields and compensate livestock owners for any injuries caused when the animals are chased out of gardens. These contrasting institutions and land use/land tenure norms highlight the importance of institutional perspectives to divergent adaptation, which must be reconciled to define the way to most benefit multiple actors without giving preference to one or the other. In the case of Droum, gardening has the potential to limit pastoral activities, prompt conflicts, and enhance vulnerability of pastoral groups if commonly-shared resources continue to be enclosed with impunity. Valley lakes are a highly strategic pastoral resource and the current institutions in Droum promote a land regime that usurps these pastoral commons and furthers the establishment of fields and enclosures in the pastoral zone. Democratically elected officials in Droum voice their 'powerlessness' to uphold laws in ways that are contrary to such norms of the population, due in part to the dominant 'land to the tiller' norms (Fig. 8). Tillia's institutions, contrariwise, are motivated by a multiple land tenure regime including common pool resource management. Within this institutional makeup, gardening is accepted as a government-promoted adaptation to drought, yet local norms and government actors prevent complete enclosure of pastoral lakes. Moreover, the appropriation of land and water resources through cultivation represents a model of land tenure demonstrated in southern Niger (Fig. 8). While such models can prevent damage to the production of gardeners, the re-possession and privatization of pastoral water resources is not being successfully averted.

Multiple forms of commodification further shift the adaptive capacities of pastoralists. As shown primarily through the Droum case study, institutions provide support to gardeners through seeds, tools, and technical services for the production of garden produce. On the contrary, there is a near void of support to the development of pastoral resources in Tillia and Droum. While

Table 7

Frequency of statements about natural resource management in both locales. Highlighted cells represent important trends or comparisons between localities.

\begin{tabular}{ll}
\hline Type of Response & Locale: Droum Phase II \\
\hline Perceive that pastoral zone is territory of pastoralists & 4 \\
Livestock corridors: Multiple benefits & 1 \\
Livestock corridors: Problems & 7 \\
Water access (pos.): Corridors are sufficient & 0 \\
Water access (pos.): No access problems & 0 \\
Water access (neg.): Dangerous & 4 \\
Natural Resource Management: Not functional & 20 \\
Natural Resource Management: Functional & 7
\end{tabular}




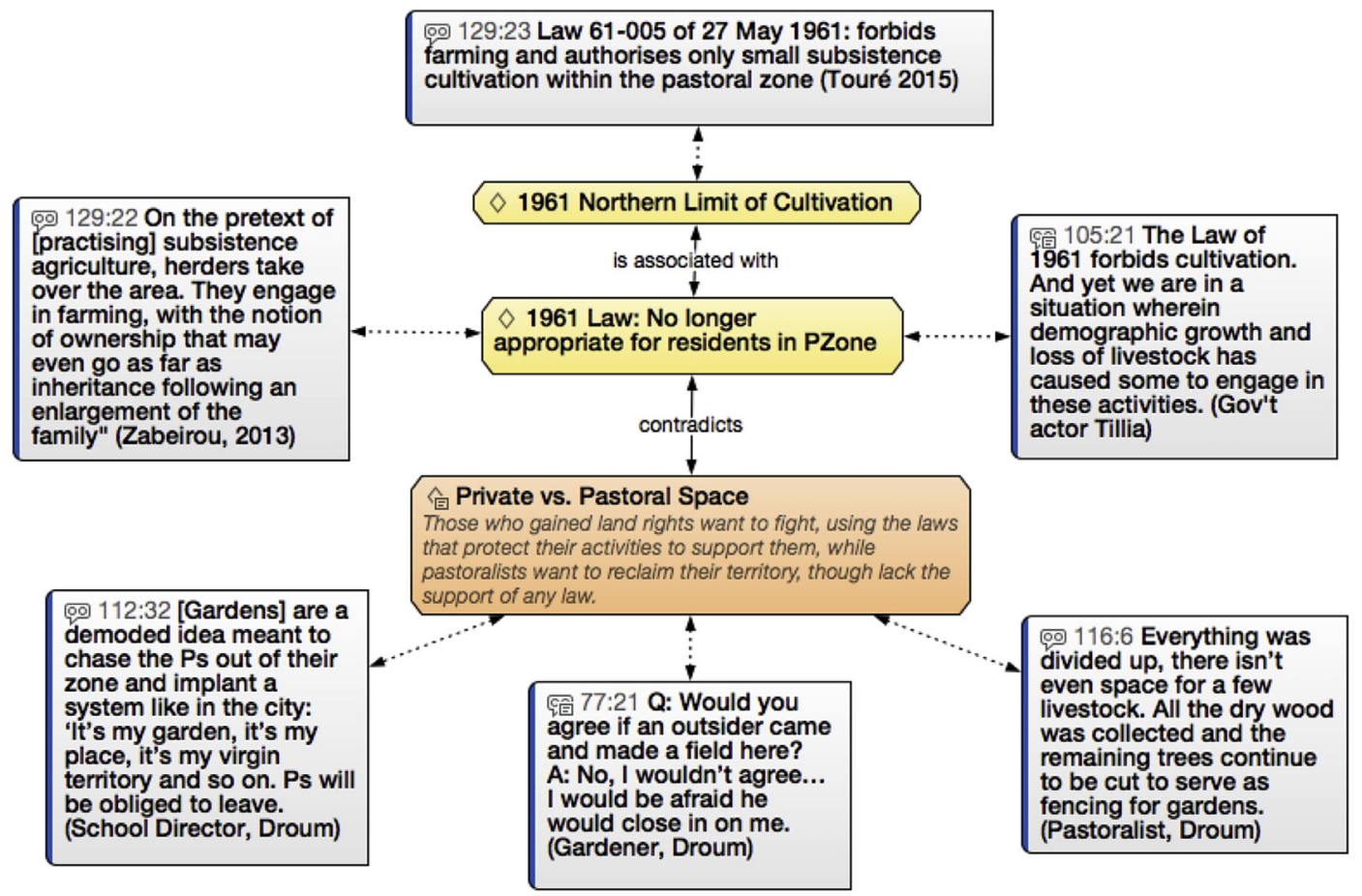

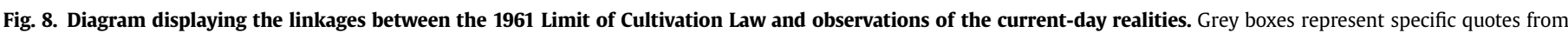
research participants, identified by the number before the colon (e.g. 105:21 is Participant 105). Ps represents pastoralists.

innovations in garden production would provide essential nutrients, the lack of gardeners selling their produce in markets demonstrates the low viability of this activity. On the contrary, the process of enclosure of pastoral resources is highly lucrative for gardeners. Fodder sales (primarily collected hay stored in garden plots), project aid (grain, water infrastructure, seeds, tools), wood (trees within garden plots), and water sales demonstrate the benefits to a garden 'investment' in the valley lakes. Yet, these activities represent a divergent adaptation in the way resources are shifted from common pool to private commodities, contributing to both new models of resource provision and greater potential conflicts over the loss of pastoral adaptive capacities. Ironically, pastoralism produces the highest revenue for state coffers through multiple marketable products such as milk, meat, skins, all of which are taxed at a higher ratio than cultivated products (Marty and Bonnet, 2006). This demonstrates the economically irrational nature of certain of the pastoral enclosures.

The transformation of the pastoral zone into a contested landscape will continue unabated, especially due to the agreed usefulness of irrigated gardening in supporting livelihoods facing climate variability in Niger. Yet, under what conditions should such gardens and their respective enclosures be established (see also Torou et al., 2013)? Enclosures redefine the political and social order of a system with new rules and institutions on how the environment is accessed and managed (Schmidt and Pearson, 2016), who benefits, and who is able to decide on boundaries. The pastures in Niger are being lost due to enclosure, pushing the remaining pastoral groups into smaller areas and limiting mobility and adaptive capacity. Enclosure undermines common pool resource management by creating competition over access to and use of shared natural resources, and enclosures multiply at surprisingly high rates across the pastoral zone. Most importantly, it usurps the traditional systems of common pool management within the territory. While the aim of gardens is to provide adaptations to vulnerable groups, the local institutions have not managed to ensure the continuing viability of common pool resource systems, as shown more definitively in the Tillia example.

\section{Conclusion}

Contestation across a landscape where commons are shifting to private land use regimes represent a key challenge facing institutions managing divergent adaptation to climate change. In this case, common pool access rights are threatened by productivist norms, which shift the traditional pastoral practices of reciprocity, pasture management, and drought adaptation by enclosing common water resources. This article examines these enclosures using the framework 'divergent adaptation to climate change' (Snorek et al., 2014), which highlights the unequal adaptive capacities of multiple actor groups in a shared ecosystem. The methodology that best illustrates the case studies couples a political ecology approach with a remote sensing-based visual interpretation and change detection using very high-resolution satellite images. This represents a new combined approach to the study of enclosures and contested landscapes in Niger's pastoral zone, which have not yet been exploited using remote sensing. In the two study sites, Tillia and Droum, the remote sensing analysis showed that most significant change between archive imagery (acquired between 2003 and 2006) and new imagery (2012 and 2013) is a conversion of previously uncultivated land into areas of closed and open fences. Moreover, shifts between classes conclude to dynamic changes of enclosed areas, most significantly from fenced areas into uncultivated land (both study sites), as well as cultivated fields without fences into fenced areas or uncultivated land, resulting in a loss of cultivated fields without fences, while enclosures are increasing. In these two different study sites (Tillia, Droum) of Niger's official pastoral zone, similar processes were found, which demonstrates that these shifts across the pastoral landscape should be identified and quantified for land regime changes in pastoral areas across the Sahel. 
In the two case studies presented in this article, irrigated gardening tends to promote land use regime changes, which are related to perceptions that common land is available to and can be possessed by "the tiller." In Droum, institutions recognize but do not enforce the rules relevant to proper management of pastoral land and water, promoting greater contestation and conflict between users, and the commodification of commonly shared water resources. In the Tillia case, the enforcement and protection of common pool resources (the northern half of a seasonal lake) has demonstrated greater cooperation between gardening and pastoral groups, which is benefitted by established rules (Snorek et al., 2014) and norms to protect the commons. In Tillia, pastoral resources are more properly managed: there is less enclosure of the lake water resources, the priority rights of pastoralists are recognized and enforced, and external government and non-governmental projects support mutually beneficial activities for both groups; a formula that has resulted in reduced conflict dynamics related to gardening as a divergent adaptation.

Legislation has existed since the 1960s to manage the pastoral system in Niger, but enforcement is frequently absent, as demonstrated in the Droum case. To reduce the prevalence of divergent adaptation and conflict dynamics in Niger it is recommended that local and sub-national leaders take an integrated approach to climate change adaptation including the de-institutionalization of inappropriate norms such as the "land to the tiller" concept to more proactive and preventative enforcement of existing land legislation. It is also recommended that water resources remain open, abundant, and available for both pastoral and irrigation activities. Thus, the privatization of the seasonal lake water should be reduced and livestock corridors, wells, and access areas should be maintained, especially in areas such as Droum where enclosure is more prevalent. Development and adaptation planning would benefit from a thorough analysis of the potentiality of divergent adaptation and its social dynamics prior to the implementation phase. Such recommendations would result in more sustainable and equitable adaptation and better respond to the wider and more complex shifts occurring in Niger's pastoral zone for both actor groups.

The enclosure of pastoral resources is nothing new. As a divergent adaptation, it is endemic to the dominant patterns of development. Yet, the land use regime shifts can be managed in ways that preserve the commons and enhance cooperation. By using remote sensing and political ecology to study and quantify these adaptations brings about a clearer understanding of the potential contestation taking place in a developing landscape, which hopefully can bring about more sound policy making. While gardening in the pastoral zone reduces vulnerability for some, these case studies have demonstrated that such a divergent adaptation need not produce conflict or be implemented in a way that eliminates strategic common pool resource regimes. However, without respect for these multiple land use regimes, conflict and uneven development will result from this divergent adaptation. We recommend that a broader investigation of this type be carried out in the Sahel, given especially more recent investments in the region.

\section{Acknowledgments}

The research was funded as part of the three-year European Commission Seventh Framework Program CLICO (244443) (Climate Change, Hydro-Conflict, and Human Security) program (FP7), devoted to the study of climate change. Remote sensing very high-

\footnotetext{
1 One example is the World Bank's Regional Sahel Pastoralism Support Project (PRAPS) in Sahel's pastoral system in six countries (Burkina Faso, Niger, Mali, Chad, Senegal, and Mauritania).
}

resolution data (Quickbird-2 and WorldView-1) have been provided by European Space Imaging (EUSI), and the data copyright is originally with DigitalGlobe and is granted to the authors for the purpose of this article. RapidEye data has been provided on behalf of the German Aerospace Centre through funding of the German Federal Ministry of Economy and Energy. The authors thank CLICO research assistants Youssouf Wadine and Moussa Abdourahamane, project coordinators Giorgos Kallis and Christos Zografos for their intellectual contributions, and Sandra Funk and Johannes Schaal for assisting with digitalization and photo-interpretation of very high resolution satellite imagery. The facts and opinions expressed in this paper are those of the authors and not necessarily those of the United Nations University.

\section{References}

Adger, N., Paavola, J., Huq, S., 2006. Toward justice in adaptation to climate change. In: Adger, N., Paavola, J., Huq, S., Mace, M.J. (Eds.), Fairness in Adaptation to Climate Change. MIT Press, Cambridge, pp. 1-22.

Adger, W.N., Pulhin, J.M., Barnett, J., Dabelko, G.D., Hovelsrud, G.K., Levy, M., Oswald Spring, Ú., Vogel, C.H., 2014. In: Field, C.B., Barros, V.R., Dokken, D.J., Mach, K.J., Mastrandrea, M.D., Bilir, T.E., Chatterjee, M., Ebi, K.L., Estrada, Y.O., Genova, R.C., Girma, B., Kissel, E.S., Levy, A.N., MacCracken, S., Mastrandrea, P.R., White, L.L. (Eds.), Human Security. in: Climate Change 2014: Impacts, Adaptation, and Vulnerability. Part a: Global and Sectoral Aspects. Contribution of Working Group II to the Fifth Assessment Report of the Intergovernmental Panel on Climate Change. Cambridge University Press, Cambridge, United Kingdom and New York, NY, USA, pp. 755-791.

Akiwumi, K., Butler, D.R., 2008. Mining and environmental change in Sierra Leone, West Africa: a remote sensing and hydro geomorphological study. Environ. Monit. Assess. 142, 309-318. http://dx.doi.org/10.1007/s10661-007-9930-9.

Barrell, J., 1983. The Dark Side of Landscape: the Rural Poor in English Painting 1730-1840. Cambridge University Press.

Bender, B., 1998. Stonehenge: Making Space. Berg, Oxford, pp. 97-131, 1998.

Bermingham, A., 1986. Landscape and Ideology: the English Rustic Tradition. University of California Press, pp. 1740-1860.

Birks, H.H., Birks, H.J.B., Kaland, P.E., Moe, D., 1988. The Cultural Landscape: Past, Present, and Future. Cambridge University Press, Cambridge.

Brandt, M., Verger, A., Diouf, A.A., Baret, F., Samimi, C., 2014a. Local vegetation trends in the Sahel of Mali and Senegal using long time series FAPAR satellite products and field measurement (1982-2010). Remote Sens. 6 (3), 2408-2434.

Brandt, M., Romankiewicz, C., Spiekermann, R., Samimi, C., 2014b. Environmental change in time series-An interdisciplinary study in the Sahel of Mali and Senegal. J. Arid Environ. 105, 52-63.

Brouwer, J., 2009. The seasonal role of isolated wetlands in the Sahel: key resources for people and biodiversity, under pressure from global change. In: Conference Proceedings from "Seasonality Revisited" International Conference at the Institute of Development Studies. UK 8-10 July, 2009.

Bryan, P.W., 1931. The cultural landscape. Geography 16 (No. 4 (DECEMBER, 1931)), $273-284$.

Cheria, A., Edwin, 2011. Towards a Vocabulary of Commons. Conference Paper. Sustaining Commons: Sustaining Our Future, the Thirteenth Biennial Conference of the International Association for the Study of the Commons, Hyderabad, India, January 10-14.

Cosgrove, D.E., 1984. Social Formation and Symbolic Landscape. The University of Wisconsin Press, Madison.

Cotula, L., 2012. The international political economy of the global land rush: a critical appraisal of trends, scale, geography and drivers. J. Peasant Stud. 39 (3-4), 649-680. http://dx.doi.org/10.1080/03066150.2012.674940.

Dardel, C., Kergoat, L., Hiernaux, P., Mougin, E., Grippa, M., Tucker, C.J., 2014. Regreening Sahel: 30 years of remote sensing data and field observations (Mali, Niger). Remote Sens. Environ. 140, 350-364.

Desanker, P., Magadza, C., 2001. Africa. IPCC Working Group II, pp. 489-525 (Chapter 10). Accessed 12 June 2012. http://www.grida.no/climate/ipcc_tar/ wg2/pdf/wg2TARch-ap10.pdf.

Dube, O.P., Pickup, G., 2001. Effects of rainfall variability and communal and semicommercial grazing on land cover in southern African rangelands. Clim. Res. 17, 195-208.

Duinveld, M., Van Assche, K., 2011. The power of tulips: constructing nature and heritage in a contested landscape. J. Environ. Policy Plan. 13 (2), 79-98.

Elmqvist, B., Khatir, A.R., 2007. The possibilities of bush fallows with changing roles of agriculture - an analysis combining remote sensing and interview data from Sudanese drylands. J. Arid Environ. 70 (2), 329-343.

Eriksen, S., Aldunce, P., Bahinipati, C.S., Martins, R.A., Molefe, J.I., Nhemachena, C. OBrien, K., Olorunfemi, F., Park, J., Sygna, L., Ulsrud, K., 2011. When not every response to climate change is a good one: identifying principles for sustainable adaptation. Clim. Dev. 3 (1), 7-20. http://dx.doi.org/10.3763/cdev.2010.0060.

Favreau, G., Nazoumou, Y., Leblanc, M., Guéro, A., Goni, I.B., 2012. Groundwater resources increase in the iullemmeden basin, west Africa. In: Treidel, H., Martin-Bordes, J.L., Gurdak, J.J. (Eds.), Climate Change Effects on Groundwater 
Resources: a Global Synthesis of Findings and Recommendations (International Contributions to Hydrogeology, vol. 27. CRC Press Inc $<x>$, Leiden, The Netherlands, pp. 113-128. Chap. 7.

FEWSNET, 2011. Niger Food Security Outlook Update (FEWSNET). USAID. November 2012.

Goldsmith, E., Hildyard, N., Bunyard, P., McCully, P. (Eds.), 1992. Ecol. Whose Common Future? A Special Issue 22 (4), 4 July/Aug 1992. Accessed Online: 9 October 2015. http://exacteditions.theecologist.org/read/resurgence/ecologist-vol-22no-4-jul-aug-1992-5345/1/2/.

Hammel, R., 2005. Politiques de développement pastoral au Sahel. Les ambitions de développement de la coopération internationale et la dynamique du système pastoral nigérien. Analyses comparative et historique. Mémoire de Recherche soumis a l'Institut Universitaire d'études du développement, IUED, Genève.

Hengsdijk, H., van Kuelen, H., 2002. The effect of temporal variation on inputs and outputs of future-oriented land use systems in West Africa. Agric. Ecosyst. Environ. 91, 245-259.

Horion, S., Fensholt, R., Tagesson, T., Ehammer, A., 2014. Using earth observationbased dry season NDVI trends for assessment of changes in tree cover in the Sahel. Int. J. Remote Sens. 35 (7), 2493-2515.

Illich, I., 1983. Silence Is a Commons. Coevolution Quarterly. Accessed online on 3 August 2016. http://www.preservenet.com/theory/Illich/Silence.html.

Kloos, J., Gebert, N., Rosenfeld, T., Renaud, F.G., 2013. Climate Change, Water Conflicts and Human Security: Regional Assessment and Policy Guidelines for the Mediterranean. Middle East And Sahel. United Nations University: Institute for Environment and Human Security (UNU-EHS). No. 10. http://www.clico.org/ final-report/.

Lukas, M.C., 2014. Eroding battlefields: land degradation in Java reconsidered. Geoforum 56, 87-100.

Mardsen, T., 1995. Beyond agriculture ? Regulating the new rural spaces. J. Rural Stud. 11 (3), 285-296.

Marty, A., Bonnet, B., 2006. Nord-Tahoua (Niger): le pastoralisme survit aux changements. Rev. Grain Sel No 34-35, 14-15.

Mbow, C., Brandt, M., Ouedraogo, I., de Leeuw, J., Marshall, M., 2015. What four decades of earth observation tell us about land degradation in the Sahel? Remote Sens. 7 (4), 4048-4067.

Mohamadou, A., 2010. Foncier, pouvoirs locaux et décentralisation dans le département de Dakoro (Niger). Bulletin de l'APAD, pp. 31-32. http://apad. revues.org/4052.

Moser, L., Voigt, S., Schoepfer, E., Palmer, S., 2014. Multi-temporal wetland monitoring in sub-Saharan west-Africa using medium resolution optical satellite data. Selected Topics in applied earth observations and remote sensing. IEEE J. 7 (8), 3402-3415.

Ngaido, T., 1995. Making Laws and Building Institutions in the Sahel - the Case of Niger, No. 6/vol. 95, pp. 19-22. Entwicklung und ländlicher raum.

Ngaido, T., 2000. Can pastoral institutions perform without access options? In: McCarthy, N., Swallow, B., Kirk, M., Hazell, P. (Eds.), Property Rights, Risk, and Livestock Development in Africa. International Livestock Research Institute (ILRI), pp. 299-325. Washington.

Nicholson, S., 2005. On the question of the "recovery" of the rains in the West African Sahel. J. arid Environ. 63 (3), 615-641.

Nyerges, E.A., Green, G.M., 2000. The Ethnography of landscape: GIS and remote sensing in the study of forest change in west African Guinea Savanna. Am.
Anthropol. 102 (2), 271-289.

Ostrom, E., 1999. Coping with the Tragedies of the Commons. Ann. Rev. Polit. Sci. 2 493-535. http://dx.doi.org/10.1146/annurev.polisci.2.1.493.

Peluso, N.L., Lund, C., 2011. New frontiers of land control: Introduction. J. Peasant Stud. 38 (4), 667-681.

Pollini, J., 2010. Environmental degradation narratives in Madagascar: from colonial hegemonies to humanist revisionism. Geoforum 41, 711-722.

Raleigh, C., 2010. Political marginalization, climate change, and conflict in African Sahel states. Int. Stud. Rev. 12, 69-86.

Reyes-García, V., Paneque-Gálvez, J., Bottazzi, P., Luz, A.C., Gueze, M., Macía, M.J. Orta-Martínez, M., Pacheco, P., 2014. Indigenous land reconfiguration and fragmented institutions: a historical political ecology of Tsimane' lands (Bolivian Amazon). J. Rural Stud. 34, 282-291. http://dx.doi.org/10.1016/ j.jrurstud.2014.02.007.

Robbins, P., 2012. Political Ecology: a Critical Introduction, second ed. WileyBlackwell, Malden, MA.

Robinson, C., Lane, M., Taylor, B., 2009. The changing and contested governance of Australia's environmental heritage. In: Lane, M., Robinson, C., Taylor, B. (Eds.), Contested Country: Local and Regional Natural Resource Management in Australia. CSIRO Publishing, Collingwood, pp. 243-246.

Schmidt, M., Pearson, O., 2016. Pastoral livelihoods under pressure: ecological political and socioeconomic transitions in Afar (Ethiopia). J. Arid Environ. 124 22-30.

Smith, N., 1990. Uneven Development: Nature, Capital, and the Production of Space, third ed. University of Georgia Press.

Snorek, J., Renaud, F., Kloos, J., 2014. Divergent adaptation to climate variability: an agro-pastoral case study from Niger. Glob. Environ. Change 29, 371-386.

Snorek, J., 2016. Contested views of the causes of rural to urban migration amongst pastoralists in Niger. In: Gebrewold, B., Bloom, T. (Eds.), Understanding Migrant Decisions: from Sub-Saharan Africa to the Mediterranean Region. Routledge, New York.

Touré, O., 2015. At the Crossroads: Analyzing the Impact of Pastoral Policies upon Pastoralists Based in Abalak, Niger. Tear fund Report. Accessed online 1 April 2016. https://landportal.info/news/2015/04/crossroads-analysing-impactpastoral-policies-upon-pastoralists-based-abalak-niger.

Torou, B.M., Favreau, G., Barbier, B., Pavelic, P., Illou, M., Sidibé, F., 2013. Constraints and opportunities for groundwater irrigation arising from hydrologic shifts in the Iullemmeden Basin, south-western Niger. Water Int. 38 (4), 465-479. http://dx.doi.org/10.1080/02508060.2013.817042.

Tschakert, P., 2007. Environmental services and poverty reduction: options for smallholders in the Sahel. Agric. Syst. 94, 75-86.

Turner, M.D., 2003. Methodological reflections on the use of remote sensing and geographic information science in human ecological research. Hum. Ecol. 31 (2) 255-279.

United States Geological Survey (USGS), 2012. A climate trend analysis of Niger Famine Early Warn. Syst. Network-Informing Clim. Change Adapt. Ser. Accessed online 10 June 2016 https://pubs.usgs.gov/fs/2012/3080/fs2012-3080.pdf.

Witmer, F.D.W., 2015. Remote sensing of violent conflict: eyes from above. Int. J. Remote Sens. 36 (9), 2326-2352. http://dx.doi.org/10.1080/ 01431161.2015.1035412.

World Bank Data, 2015. Niger Population Data. Accessed online June 16, 2016. http://data.worldbank.org/country/niger. 